九州大学学術情報リポジトリ

Kyushu University Institutional Repository

\title{
Chemical Approach to Biologically Active Substances
}

Maekawa, Kazuyuki

Laboratory of Pesticide Chemistry, Faculty of Agriculture, Kyushu University

https://doi.org/10.5109/23500

出版情報: 九州大学大学院農学研究院紀要. 21 (4)，pp.191-231，1977-07. Kyushu University バージョン：

権利関係 : 


\title{
Chemical Approach to Biologically Active Substances
}

\author{
K azuyuki M aekawa \\ Laboratory of Pesticide Chemistry, Faculty of Agriculture, \\ Kyushu University 46-02, Fukuoka 812
}

(Received March 28, 1977)

\begin{abstract}
An aim of the investigation was to prepare bioactive compounds from components of natural food or convertible ones to useful and harmless material by degradation. Particularly, some heterocyclic compounds derived from amino acids and peptidcs, guanidinopyrimidines, pseudopurines, dithianethiones, isocoumarins were considered as the object. On the whole, about 500 compounds were newly prepared and examined on their biological activities.

As for carbohydrates, oxidation with periodate, preparation of amino acid derivatives from oxidized polysaccharides, preparation of nitro- and amino-polysaccharides, synthesis of triazine derivatives from polysaccharides etc. some investigations on chemical modifications of polysaccharides were made.

The oxidation by periodate was also applied to proteins, especially some enzymes. By the oxidation, certain relationship between constitution and biological activity, expressly a role of tryptophan, was elucidated.

Two allergenic substances were isolated from liver flukes and their constitutions were clarified. The allergenic principle was an RNA linked with a small peptide. Starting from the idea of RNA-complex, a preparation of an RNA fraction from tumor cells, a complex formation of the RNA with basic polymers, and an attenuation of tumor cells by treating with the complex were described. Furthermore, by inoculating beforehand with the attenuated tumor cells, the transplantation of tumor and thereby challenge inoculation were inhibited completely.

Moreover, analyses, separations, decompositions and other subjects as to some natural products were mentioned briefly.
\end{abstract}

\section{INTRODUCTION}

Some heterocyclic compounds were prepared in order to obtain various biologically active compounds. Especially, the preparation of analogous compounds to naturally occurring carbohydrates, amino acids and nucleic acids or their new derivatives was an object of the present study. As a result, carboxyl groups of amino acids, peptidcs and proteins were incorporated into some heterocyclic rings and some new series of biologically active compounds appeared.

On the other hand, as to scission or degradative reaction, oxidation by periodate was applied at first to the further scission of cleaved furan ring. Then, inulin, mannan, xylan and starch were subjected to this reaction and further it was attempted to derive some different compounds.

By applying of the reaction to protein, the relationship between easily oxidizable constituents and abolishing of the biological activity was discussed. 
Furthermore, it was adopted to remove some side chains of peptide or to modify by binding with certain sugar molecule or other molecules, without serious change on the biological activity. Thus, glucosylamidyl-enzymes, enzymes combined with ethylene oxide, still active oxidized $\alpha$-amylase, pepsin, trypsin, lysozyme, and glucosylamidyltrypsin, etc. were prepared.

Then, three allergenic substances were isolated from Fasciola hepatica. As for a proteinic substance and a substance composed of KNA and slight amount of peptide their constitutions were scrutinized. Moreover, from the fact of developing biological activity by means of combining small peptide and RNA, the repression of tumor-transplantation was accomplished by administering complexes of basic polymers with tumor RNA as well as various RNA obtained from other sources.

In addition, some contributions were done on the related subjects.

\section{SECTION I. HETEROCYCLIC CHEMISTRY}

\section{Furan derivatives}

A cleavage reaction of furan ring was recognized at first from the reaction of hypoiodite to furfural derivatives and formation of haloform. This oxidative scission reaction was quantitatively accomplished by bromine water in an aqueous solution. The product thus obtained consumed 1 mole of periodate / mole to cleave between ketone and aldehyde (Scheme 1).

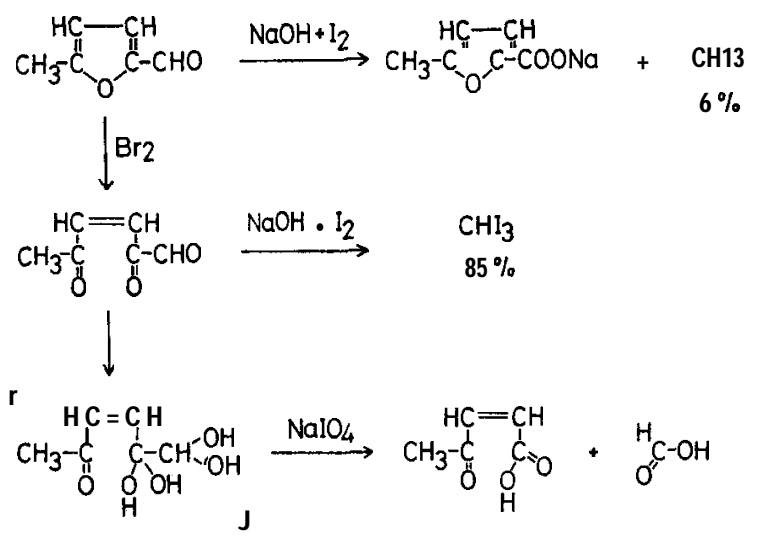

Scheme 1.

From these facts, it was inferred that the oxidative scission of furfural in the aqueous solution by bromine was carried out as follows. (Baeyer, 1877) (Scheme 2). 


$$
\begin{aligned}
& \mathrm{X}_{2} \cdot \mathrm{H}_{2} \mathrm{O} \rightleftharpoons \mathrm{HOX}+\mathrm{HX}
\end{aligned}
$$

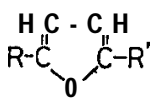

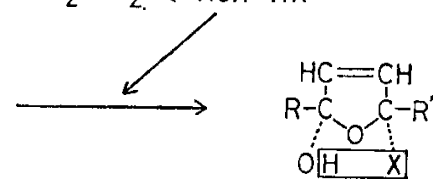

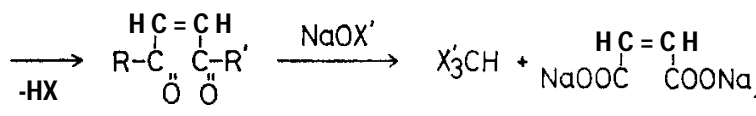

\section{Triazolopyrimidine and thiadiazolopyrimidine}

3-Amino-1, 2, 4-triazole was condensed with active methylene ketones such as ethyl cyanoacetate, acetylacetone, ethyl acetoacetate to yield corresponding 7amino-5-hydroxy-s-triazolo [1,5-a] pyrimidine, 5, 7-dimethyl-s-triazolo[1,5-a]-pyrimidine and 7-hydroxy-5-methyl-s-triazolo [1,5-a] pyrimidine (I) (Scheme 3). Then, starting from (I), some 5-methyl-7-substituted-s-triazolopyrimidines were synthesized (Kano and Makisumi, 1958). As to some of derivatives, pesticidal, herbicidal and other biological activities were examined. 5-Methyl-7-thiocyano-s-triazolo [1,5-a]pyrimidine has shown a strong antibiotic activity to $B$. subtillis as well as to Pellicularia filamentosa and Phytophthora infestans.<smiles></smiles><smiles>C=CCC(C)Br</smiles><smiles>CCOC(=O)Cn1c(C)cc(=O)n2ncnc12</smiles><smiles>[R]C(=O)CC(C)=O</smiles><smiles>[R]Oc1cc(C(C)(C)C(=O)O)nc2nc(CCCCCCCCCCC)nn12</smiles>

$$
\begin{aligned}
\mathbf{R} & =\mathrm{OEt} \\
& =\mathrm{CH}_{3}
\end{aligned}
$$


The synthesis of bicyclic and tricyclic compounds by a condensing ringclosure reaction, using $\beta$-keto-esters and 2 -amino-1, 3, 4-thiadiazolc was undertaken. About 20 derivatives of 2, 5, 6, 7-substituted thiadiazolo [3,2-a] pyrimidine were synthesized.

2-Aminobenzothiazole condensed with ethyl aceloacetate or ethyl benzoylacetate to cyclize to the tricyclic ring compounds, pyrimido $[2,1-a]$ benzothiazole in the presence of polyphosphoric acid. Schrader and Zerweck (1934) obtained 2-substituted amihobenzothiazole and no tricyclic compounds by heating the same components without PPA. The synthetic route is illustrated as follows (Scheme 4).<smiles></smiles><smiles>[R2]c1nnc(NCCCC)s1</smiles><smiles>[R2]c1nn2ccc(=O)nc2s1</smiles><smiles>[R2]c1nnc(N)s1</smiles>

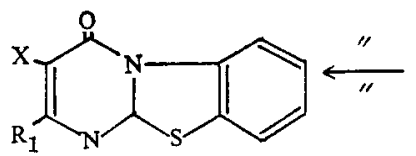<smiles>Nc1nc2ccccc2s1</smiles>

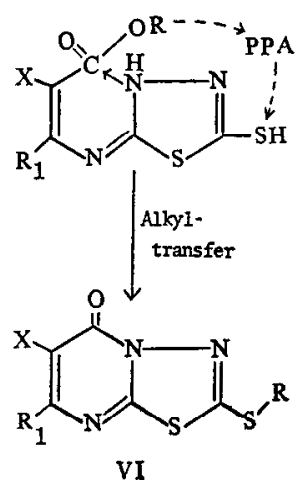

$$
\begin{aligned}
\mathrm{R}= & \mathrm{CH}_{3}, \mathrm{C}_{2} \mathrm{H}_{5} \\
\mathrm{R}_{1}=\mathrm{H}, \mathrm{CH}_{3}, \mathrm{C}_{6} \mathrm{H}_{5} & \\
\mathrm{R}_{2}= & \mathrm{H}, \mathrm{CH}_{3}, \mathrm{C}_{2} \mathrm{H}_{5}, \text { isopro } \\
& \quad \mathrm{CH}_{3} \mathrm{~S}, \mathrm{C}_{2} \mathrm{H}_{5} \mathrm{~S} \text {, isopro-S, SH } \\
\mathrm{R}_{3}= & \mathrm{H}, \mathrm{CH}_{3} \\
\mathrm{X}= & \mathrm{H}, \mathrm{Cl}, \mathrm{COOEt}
\end{aligned}
$$

Scheme 4. Syntheses of thindiazolo $[3, \mathbf{Z}-\mathbf{a}]$ pyrimidine and related compounds.

Incidentally, 2-amino-5-mercapto-1, 3,4-thiadiazole condensed with methyl (or ethyl) acetoacetatc to afford 2-methyl (or ethyl) thio-7-methyl-5-oxo-thiadiazolo$[3,2-a]$ pyrimidine. Therefore, it is evident that the alkyl of alkylmercapto group in the product originated from the alkyl group of the ester.

It has been clarified that some of these compounds have a selectively herbicidal activity between rice and barnyard grass. Especially, 2, 7-dimethyl- 
as well as 2-benzylthio-7-methyl-derivatives havt shown a high selectivity against the latter.

The ring-opening and rearrangement react ion of 7 -methyl-5H-1,3,4-thiadiazolo [3, 2-a] pyrimidine-5-one (II) and the alternativo isoneric 7-ones (XI) has been studied (Scheme 5). II $(\mathrm{R}=\mathrm{H})$ and $\mathrm{XI}(\mathrm{R}=\mathrm{H})$ gaviquantitatively through $\mathrm{N}-\mathrm{N}$ bond cleavage methylthiouracil (III) by treating with $5 \% \mathrm{NaOH}$, while they yielded 4-methyl-2-thiocyanate-6 $6(1 H)$-pyrimidone (II') by treating with liquid ammonia. By treating II and XI (R=alkyl) with $5 \% \mathrm{NaOH}$, the $\mathrm{S}-\mathrm{C}$ bond cleaved to produce the corresponding acylaminopyrimidinc derivatives (IV and IV') and 3-aminopyrimidinethione ( $\mathrm{V}$ and $\left.\mathrm{V}^{\prime}\right)$.

The treatment of 2-hydrazino derivative $\left(11 ; \mathrm{R}=\mathrm{NHNH}_{2}\right)$ with $5 \% 6 \mathrm{NaOH}$

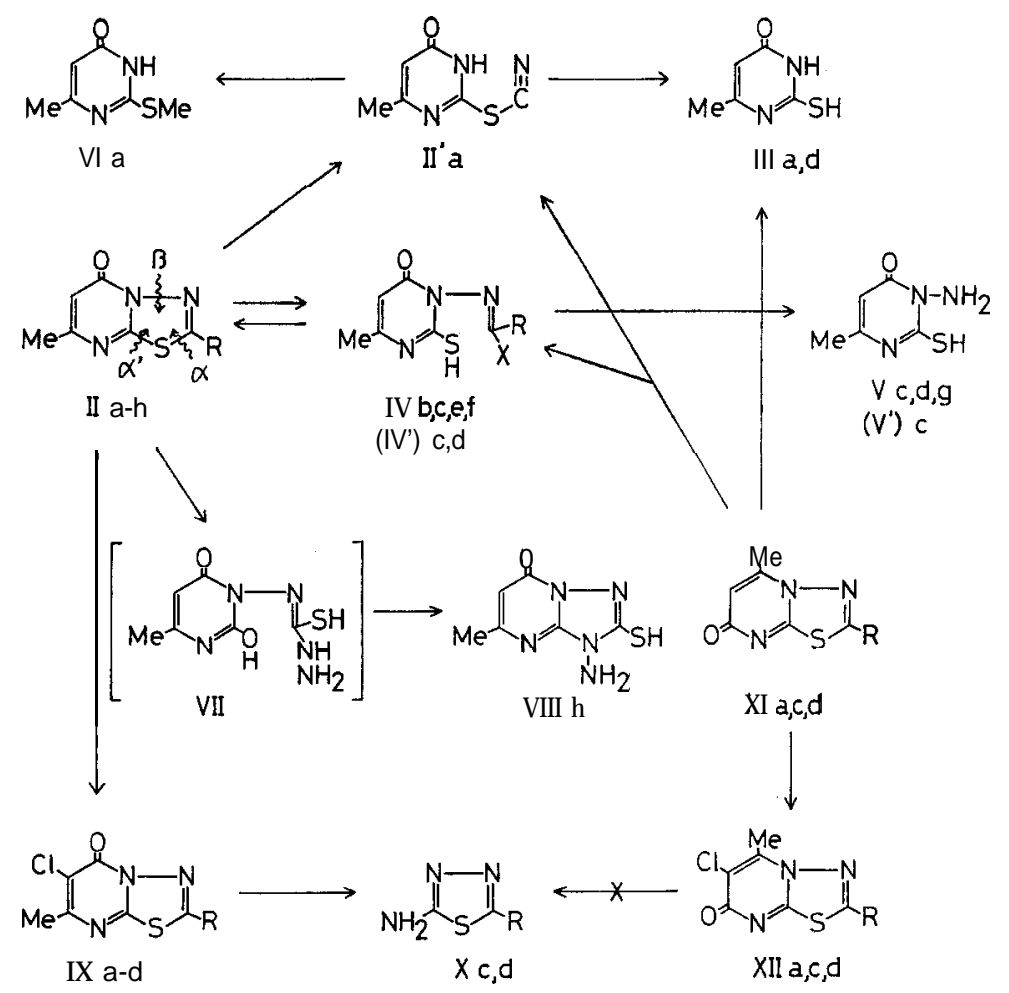
$\frac{\mathrm{R}}{\mathrm{a}: \mathrm{H}}$
$\frac{\mathrm{R}}{\mathrm{e}: \mathrm{S}-\mathrm{CH}_{3}}$
$x=\left\{\begin{array}{l}\mathrm{OH} \\ \mathrm{Et}-\mathrm{NH} \\ \mathrm{OMe}, \mathrm{OEt}\end{array}\right.$
b: $\mathrm{CH} 3$
$f: \mathrm{S}-\mathrm{C}_{2} \mathrm{H}_{5}$
g: $\mathrm{S}-\mathrm{CH}_{2}-\mathrm{C}_{6} \mathrm{H}_{5}$
d: $\mathrm{i}-\mathrm{Pr}$
$\mathrm{h}: \mathrm{NH}-\mathrm{NH} 2$
(') Isomeric compounds

Scheme 5. Scission of thiadiazolo [3,2-n] pyrimidine by alkali or chlorine. 
gave 1-amino-2-mercapto-7-methyl-5H-s-triazolo[1,5-a] pyrimidin-5-one through ring-opening and recyclization. On the other hand, the pyrimidine moiety of II ( $\mathrm{R}=\mathrm{Et}$ and $\mathrm{i}-\mathrm{Pr})$ cleaved by the action of chlorine to afford 2amino-l, 3, 4-thiadiazole (X; $\mathrm{R}=\mathrm{Et}$ and $\mathrm{i}-\mathrm{Pr}$ ).

\section{Guanidinopyrimidine}

Various N-substituted biguanides were prepared and condensed with ethyl acetoacetate, ncetylacetone and ethyl benzoylacetate. In these reactions 2-substituted guanidinopyrimidine derivatives (XIII) were produced. The biguanidc derivatives used were $\mathrm{N}$-phcnylbiguanide, $N$-( $\beta$-phenethyl) biguanide, $N$-( $p$-methylphenyl)biguanide, morpholinobiguanide, and piperidinobiguanide (Scheme 6).<smiles>[R]C(=O)CC([R])=O</smiles><smiles>[R]N([R])c1nc(N)nc(C#N)n1</smiles>

When diethyl malonate was used, the product could not be obtained, in disaccord with the earlier paper (Rackmann, 1910). Furthermore, when ethyl cyanoacrtate was used, only s-triazine derivative (XIV) was obtained.

2-Phenethylguanidino-4,6-dimethylpyrimidine inhibited almost the growth of radish roots at the concentration of $50 \mathrm{ppm}$, while at the concentration of $10 \mathrm{ppm}$ it stimulated the growth of radish roots remarkably.

On the other hand, it was also carried out that C-terminus of amino acids allowed to be incorporated into the ring of pyrimidine, by the reaction of esters of some N-blocked amino acids with 1, 3-diamines (Scheme 7). However, the yield was very poor.

\section{Benzimidazole and 1, 2, 3, 4-tetrahydropyrido [1, 2-a] benzimidazole}

$\mathrm{N}$-Blocked amino acids were condensed with o-phenylenediamine in the presence of $\mathrm{DCC}$ at $0^{\circ} \mathrm{C}$ to give derivatives of monoacyl-o-phenylenediamine. The 


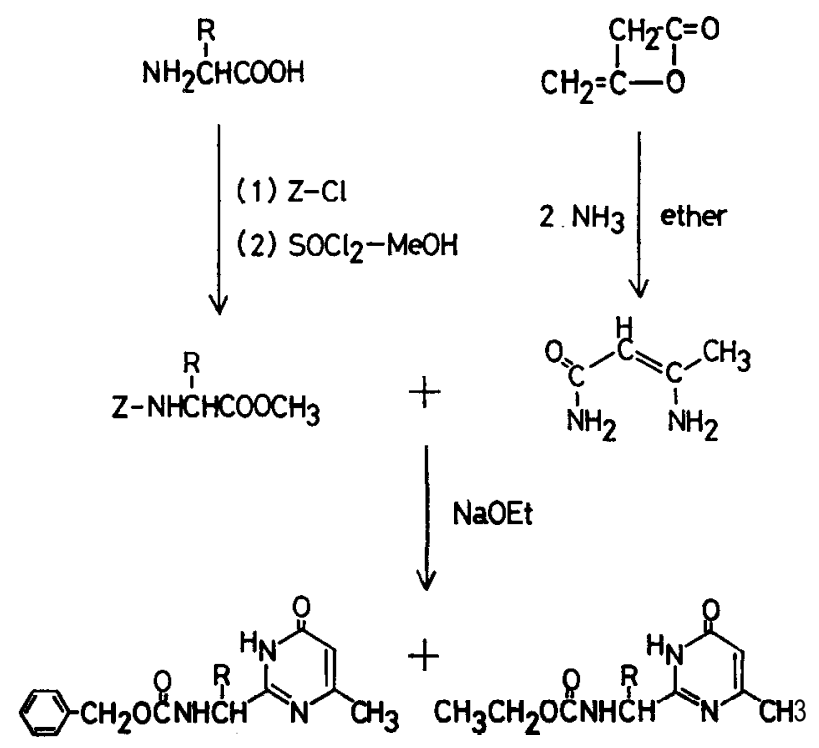

\section{Z: Carbobenzoxy \\ $\mathrm{R}$ : Side chain of amino acid}

Scheme 7.

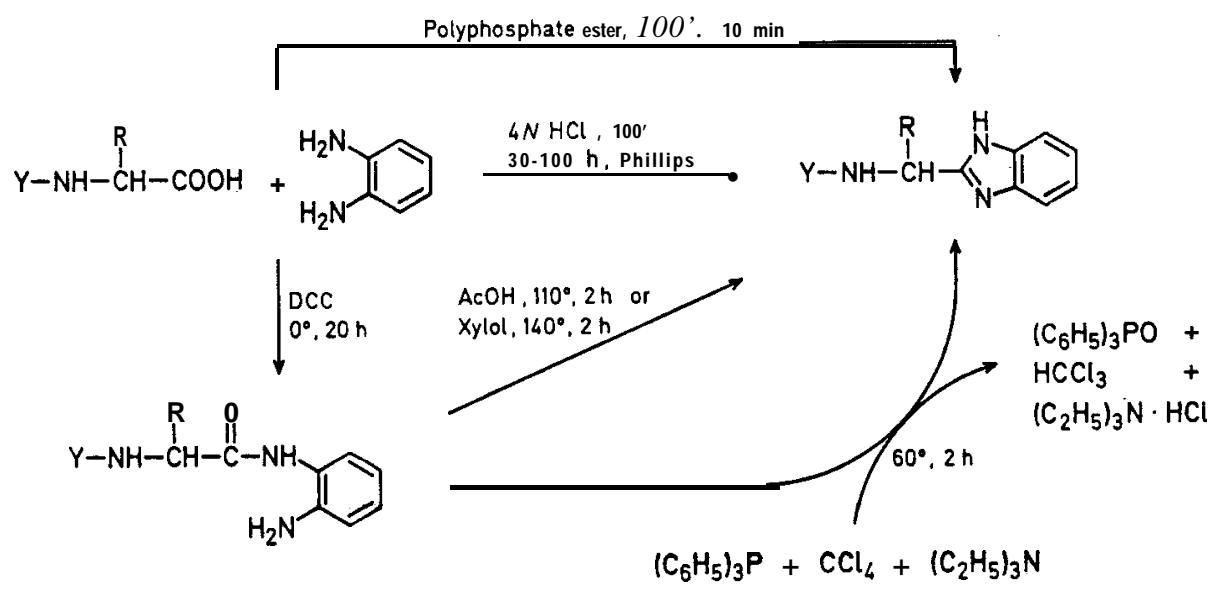

Scheme 8.

ring closure of monoacyl derivatives thus obtained was then carried out by refluxing them for $10-200 \mathrm{~min}$ in toluene, xylene or by gently heating them for $2 \mathrm{hrs}$ in acetic acid. The dehydrating cyclization by triphenylphosphine (Apple et al., 1971) was suitable for glutamine, asparagine, and threonine. By these methods, the carboxyl group of naturally occurring amino acids was all cyclized to benzimidazole ring (Scheme 8). These compounds are almost new compounds. 
Among these derivatives, there are some biologically active compounds as regulators for growth of plants or fungi.

However, by this procedure, glutamine derivative at above $75^{\circ} \mathrm{C}$ afforded a 1, 2, 3, 4-tetrahydro-1-oxo-pyrido[1,2-a] benzimidazole in good yield (Scheme 9).

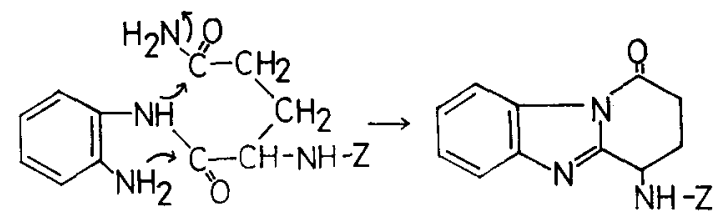

Scheme 9.

\section{Triazine derivatives}

Syntheses of substituted s-triazines were carried out by means of a ring closure of $\boldsymbol{S}$-methylguanylisothiuronium methosulfate (Eilingsfeld and Scheuer. mann, 1967) or morpholino- as well as dimethyl-biguanide with amino acid chlorides prepared from N-blocked amino acids. On the other hand, amino acid esters as well as peptide esters reacted directly with dimethylbiguanide to give triazine derivatives in fairly good yield (Scheme 10). The racemization did not occur during the second reaction.

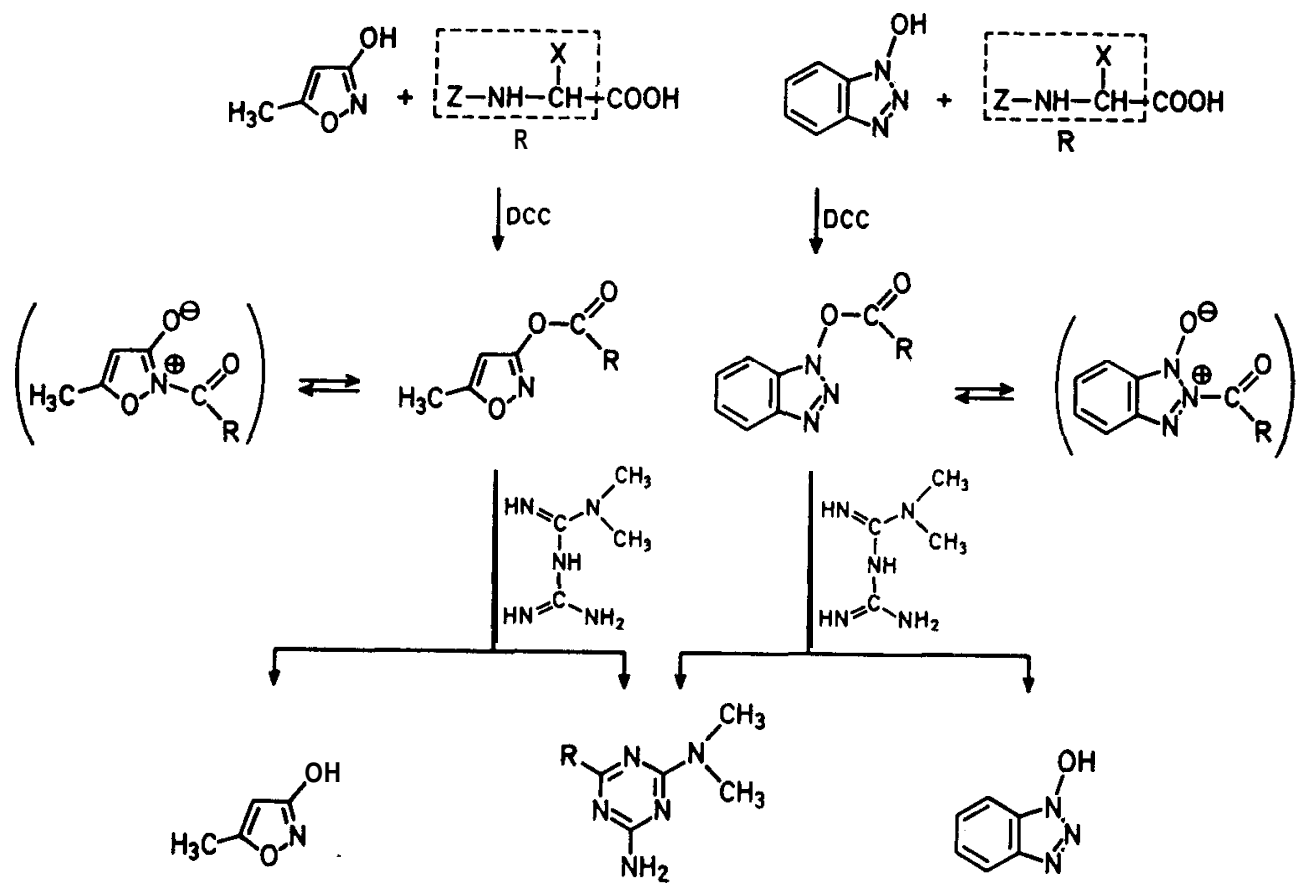

Scheme 10. Preparation of triazine derivatives through active esters, 


\section{Tetramic acid and tetronic acid}

Tetramic and tetronic acids were synthesized as follows (Scheme 11). Some derivatives of s-substituted tetramic acid inhibited strongly the growth of radish roots at very low concentrations. The compound derived by decarbox. ylation of XVI inhibited selectively outcoming of side roots of rice.
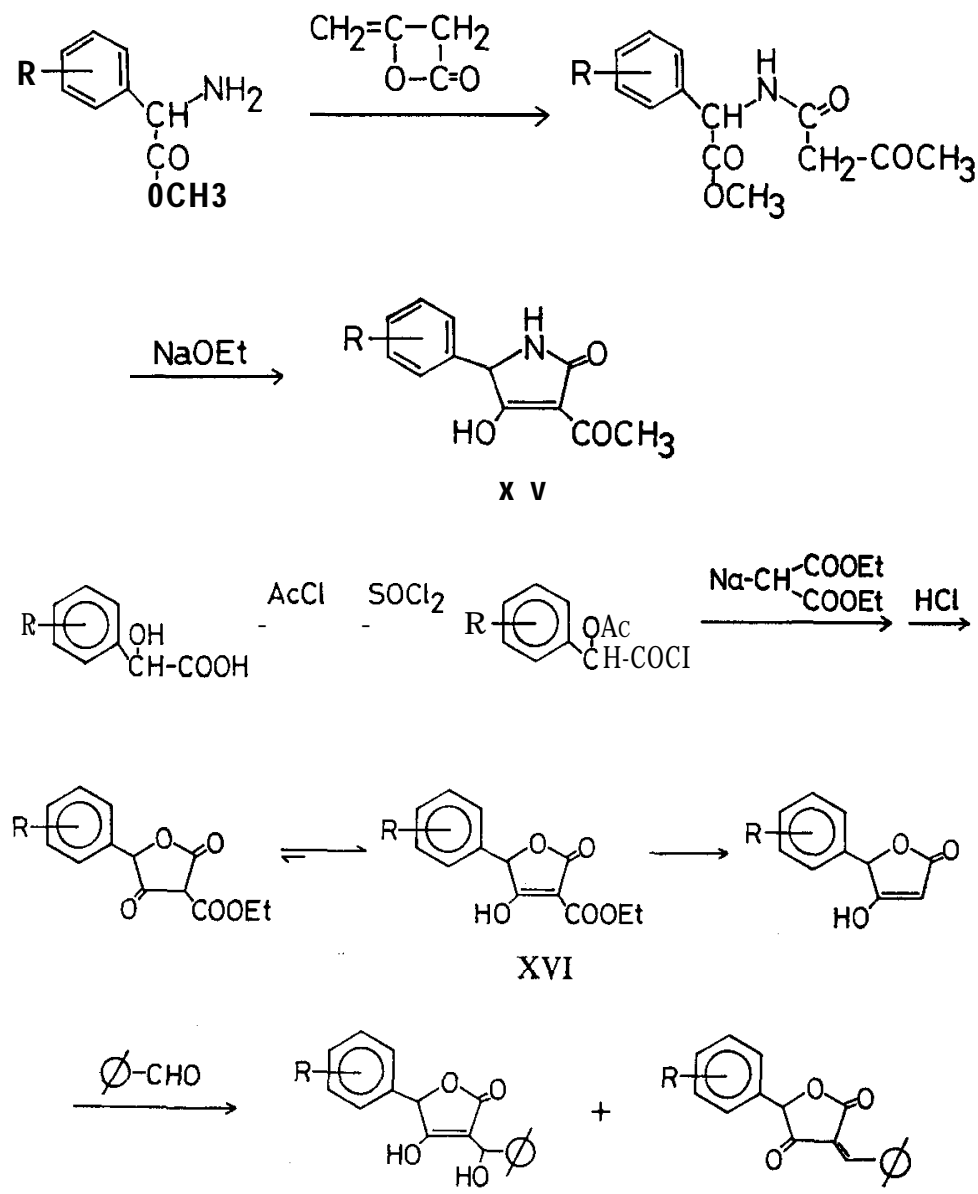

Scheme 11 .

\section{Oxadiazolo $[1,5-a]$ pyrimidine}

5-Keto- as well as 7-keto-oxadiazolo [1,5-a] pyrimidines were prepared from the reaction of derivatives of 1,3,4-oxadiazole with acetoacetate, ester of acetylene dicarboxylic acids or diketene (Scheme 12).

VIII. Isocoumarin derivatives

Substituted homophthalic acids were synthesized through various routes. 

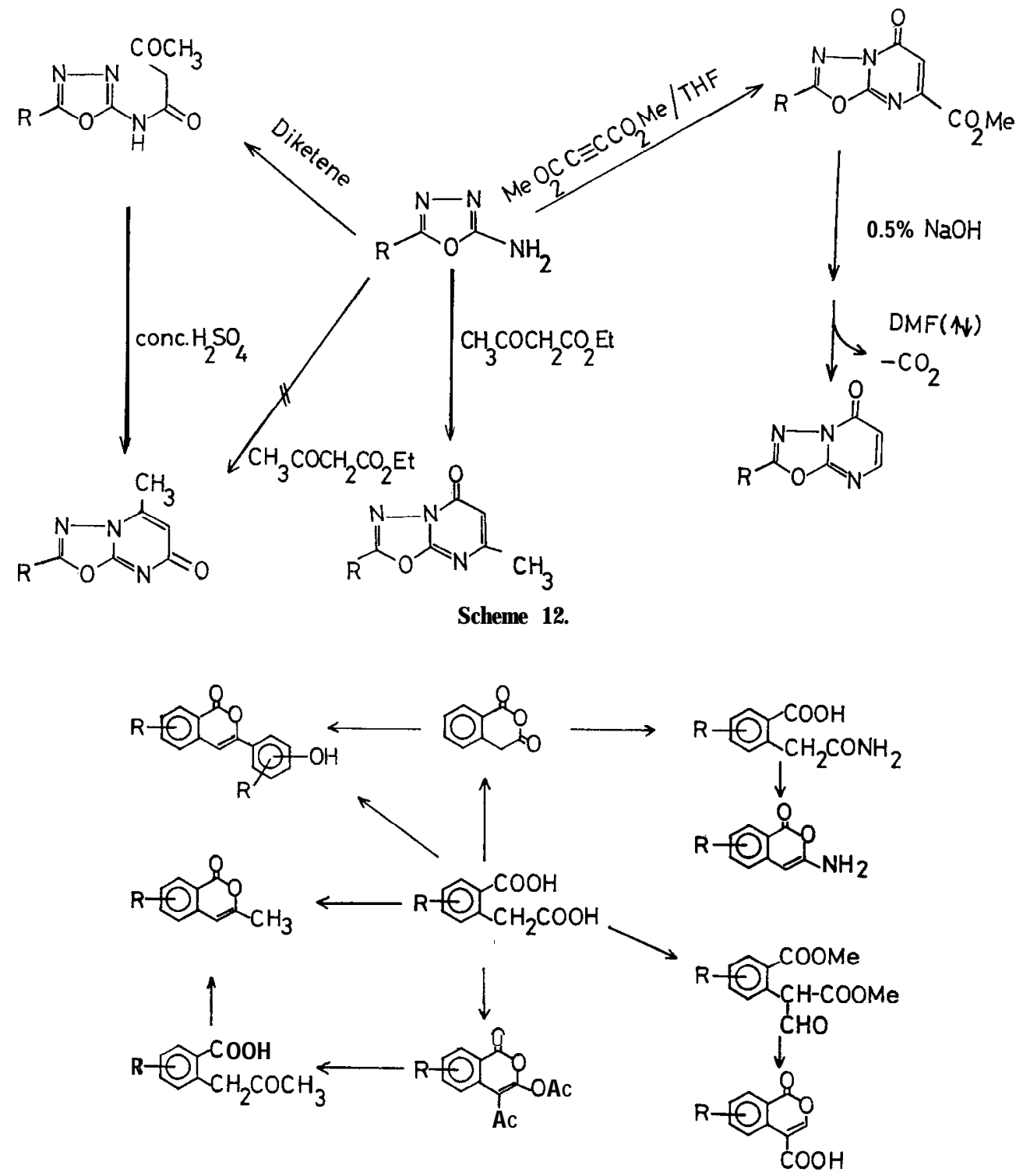

Scheme 13.

Thesc acids were derived to isocoumarin derivatives by the ring closure (Scheme 13). Thus, about 80 compounds were prepared newly. Some of them were herbicidally active.

\section{1, 3-Dithiane-2-thione derivatives}

1, 3-Diols which were prepared by various methods were converted to mesyl- 
ate. The 1, 3-dimesylated compounds were then treated with $\mathrm{Na}_{2} \mathrm{~S}$ and $\mathrm{CS}$, in a DMF solution to afford 1, 3-dithiane-2-thione in good yields (Scheme 14). About 30 compounds were newly prepared. Many of these derivatives had considerably high biological activities.

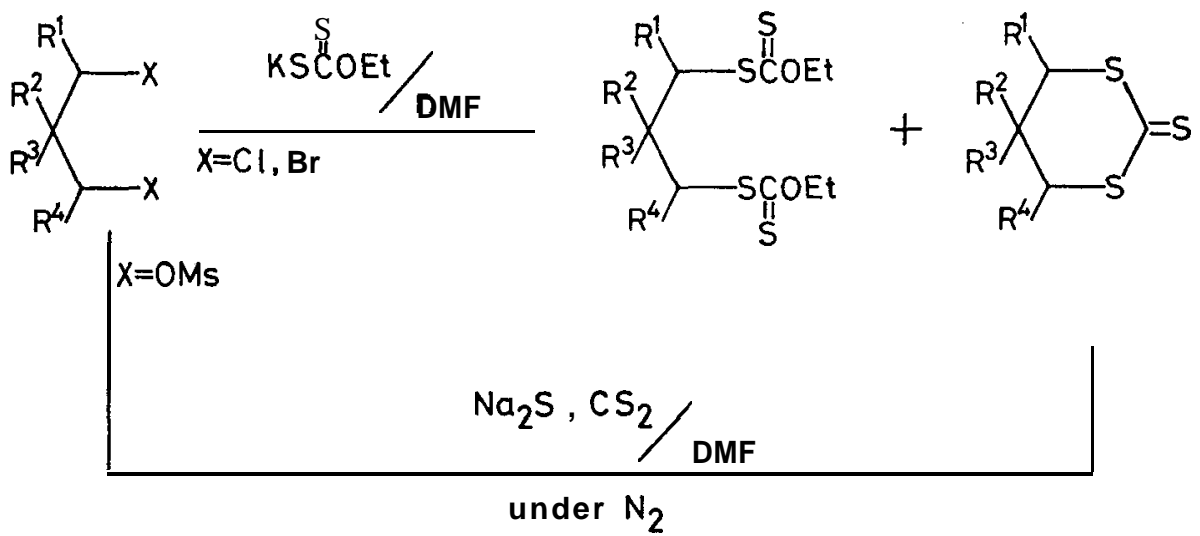

Scheme 14. Preparation of 1,3-dithiane-2-thione.

\section{Morpholinone derivatives}

Some new 2-morpholinones were synthesized by the condensation of propylene-oxide or 1, 2-butylene oxide with leucine derivatives (Scheme 15). Only 2-cyclohexylamino-1-phenylethanol had the activity against adults of Tetranychus cinabarius.

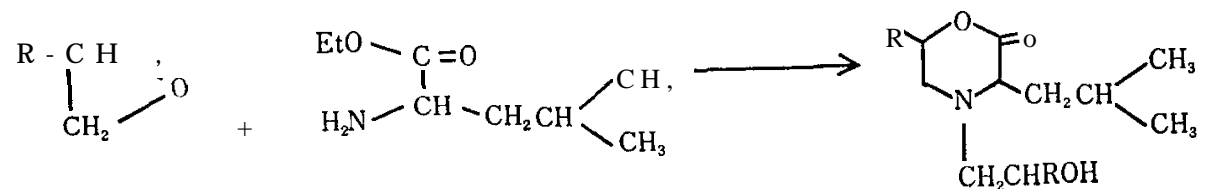

Scheme 15.

\section{2-(2'-Hydroxy-2', 2'-diphenylethyl)-8-hydroxyquinoline}

2-Methyl-8-methoxyquinoline, possessing an activated methyl group in position 2, was then reacted with isopropyl magnesium bromide and benzophenone to yield 2-(2'-hydroxy-2', $2^{\prime}$-diphenylethyl)-8-methoxyquinoline. The protecting group of C-8 was removed by hydrolysis with hydrogen bromide (Scheme 16). This compound inhibited the action of the phenol oxidase prepared from prepupae of housefly. In a dipping test of the final instar larvae of housefly, it showed some inhibitory effects on the metamorphosis. 


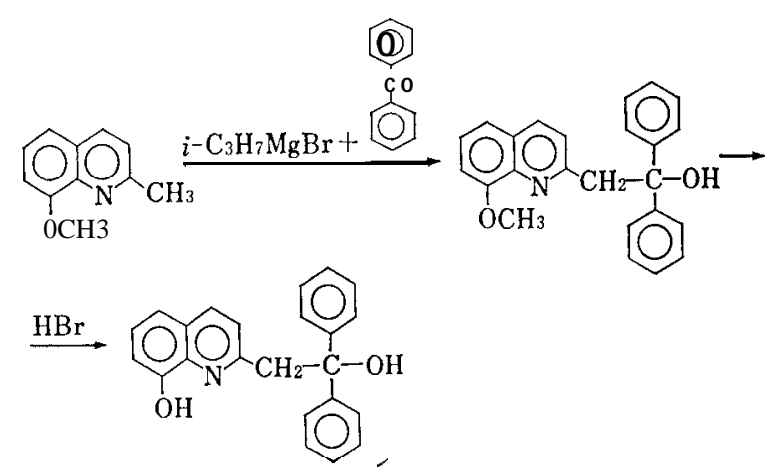

Scheme 16.

Table 1. Biologically active substances discovered by the author and collaborators.

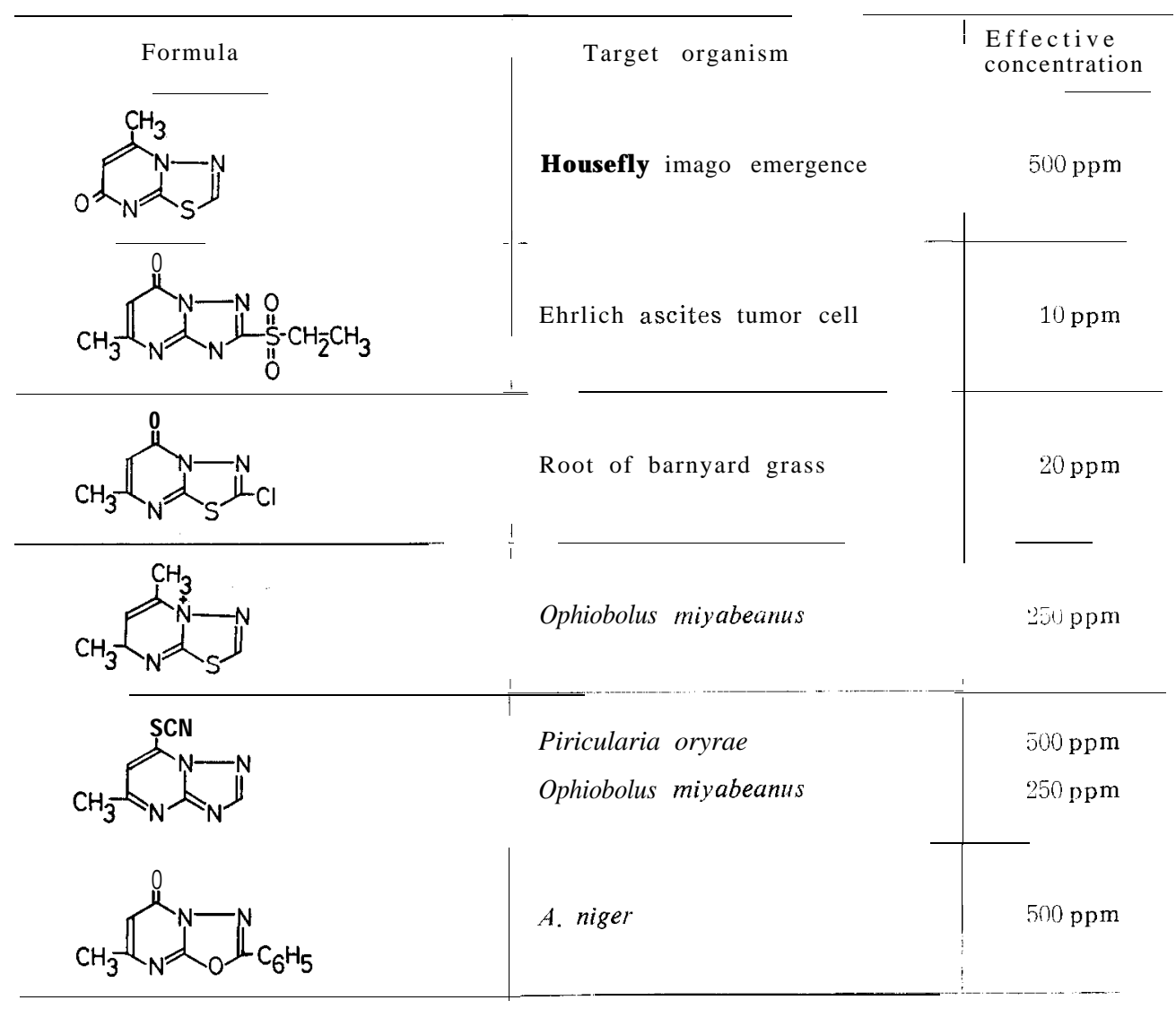


Table 1. (continued)

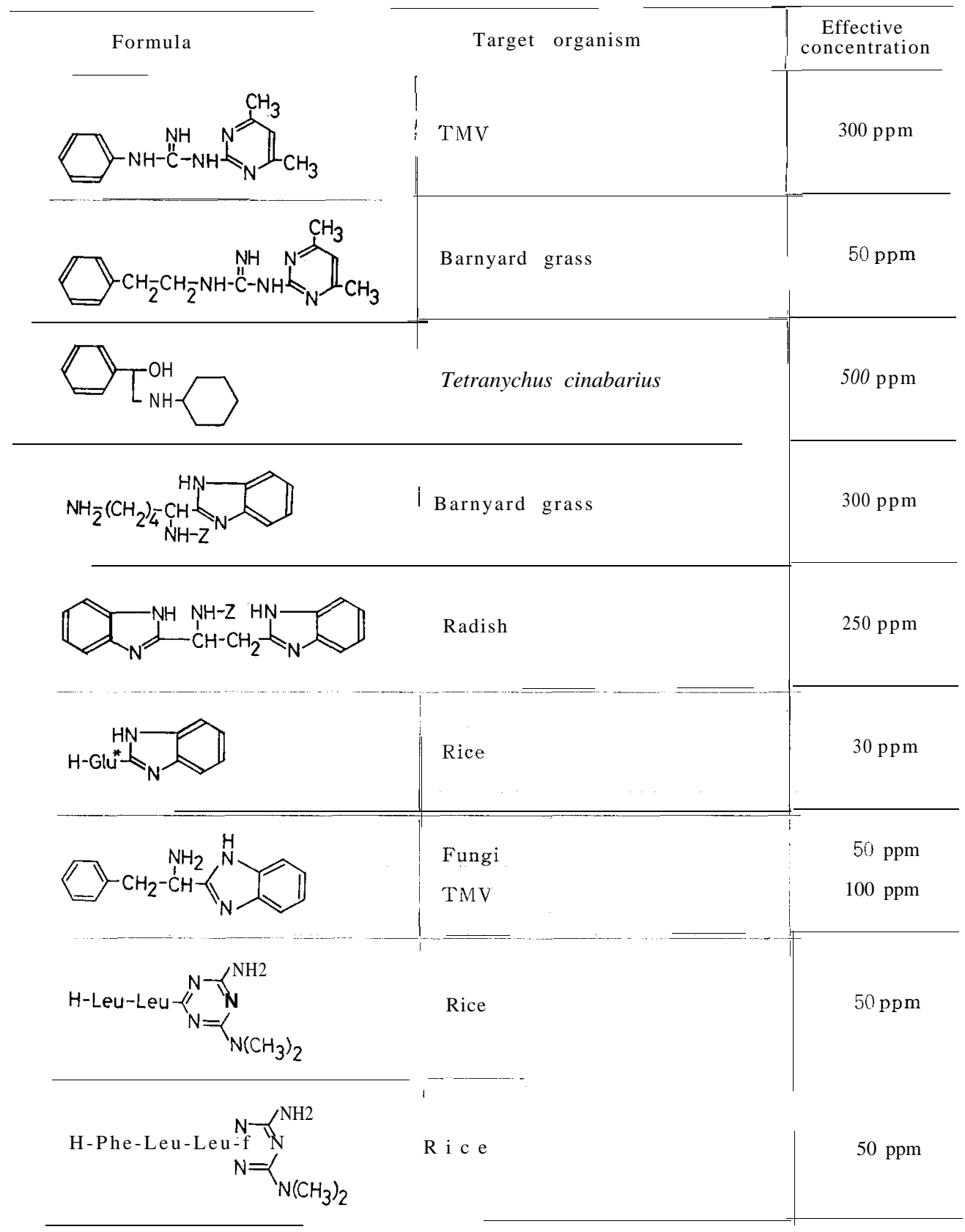


Table 1. (continued)

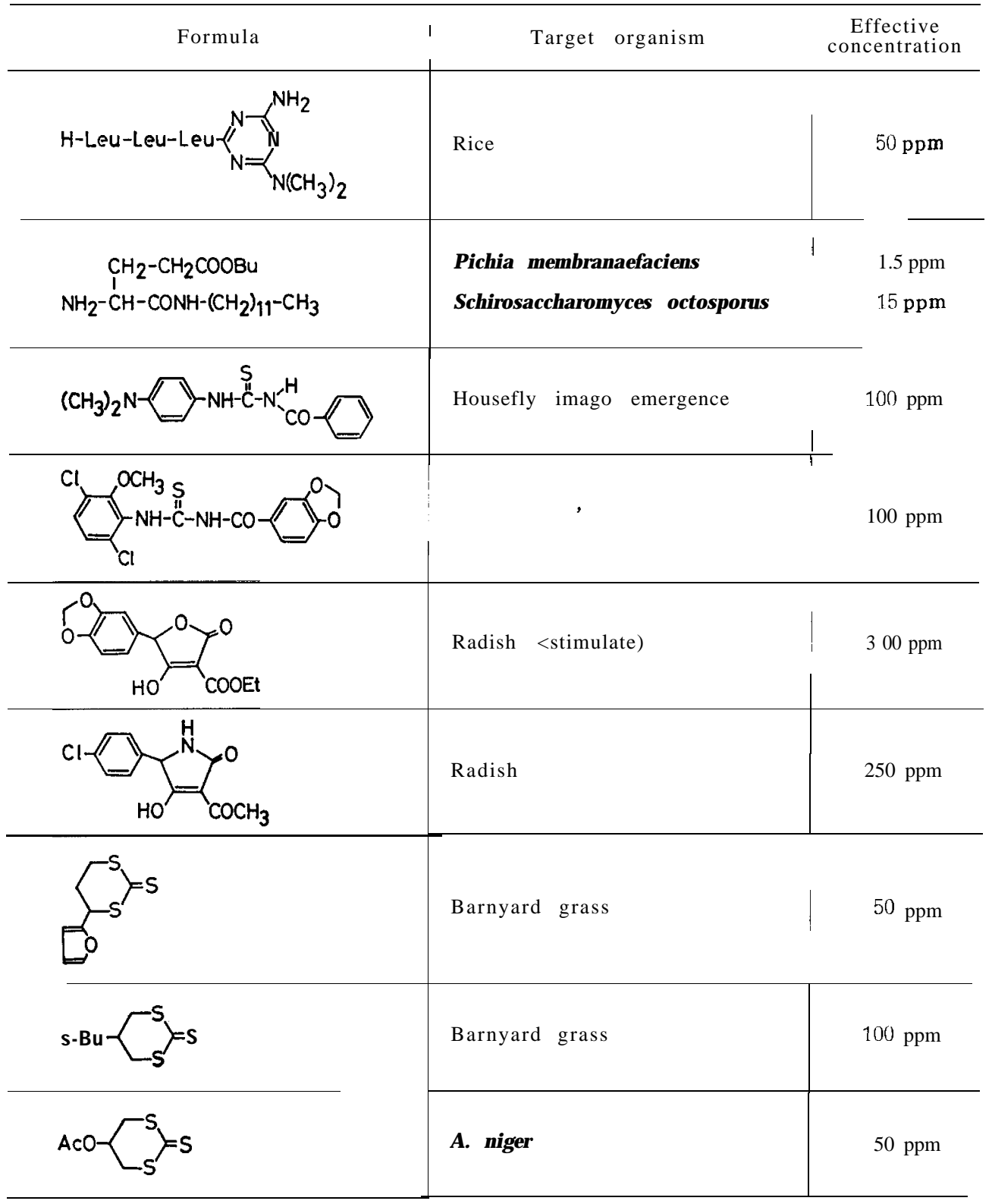




\section{SECTION II. CARBOHYDRATE CHEMISTRY}

\section{Periodate oxidation}

\section{i. Xylan}

Xylan was subjected to the oxidation by periodate. Then, oxidized xylan was hydrolyzed to identify the cleaved products. However, it was known afterward in the finish of the 2 nd world war that the similar research was already done by Jayme and Särtre (1942) during the war time.

\section{ii. Inulin}

Inulin was oxidized by periodate. The consumption of oxidant, changes of optical rotation and relative viscosity were scrutinized and the scission products were identified respectively. As to the scission reaction of inulin following scheme was proposed (Scheme 17).
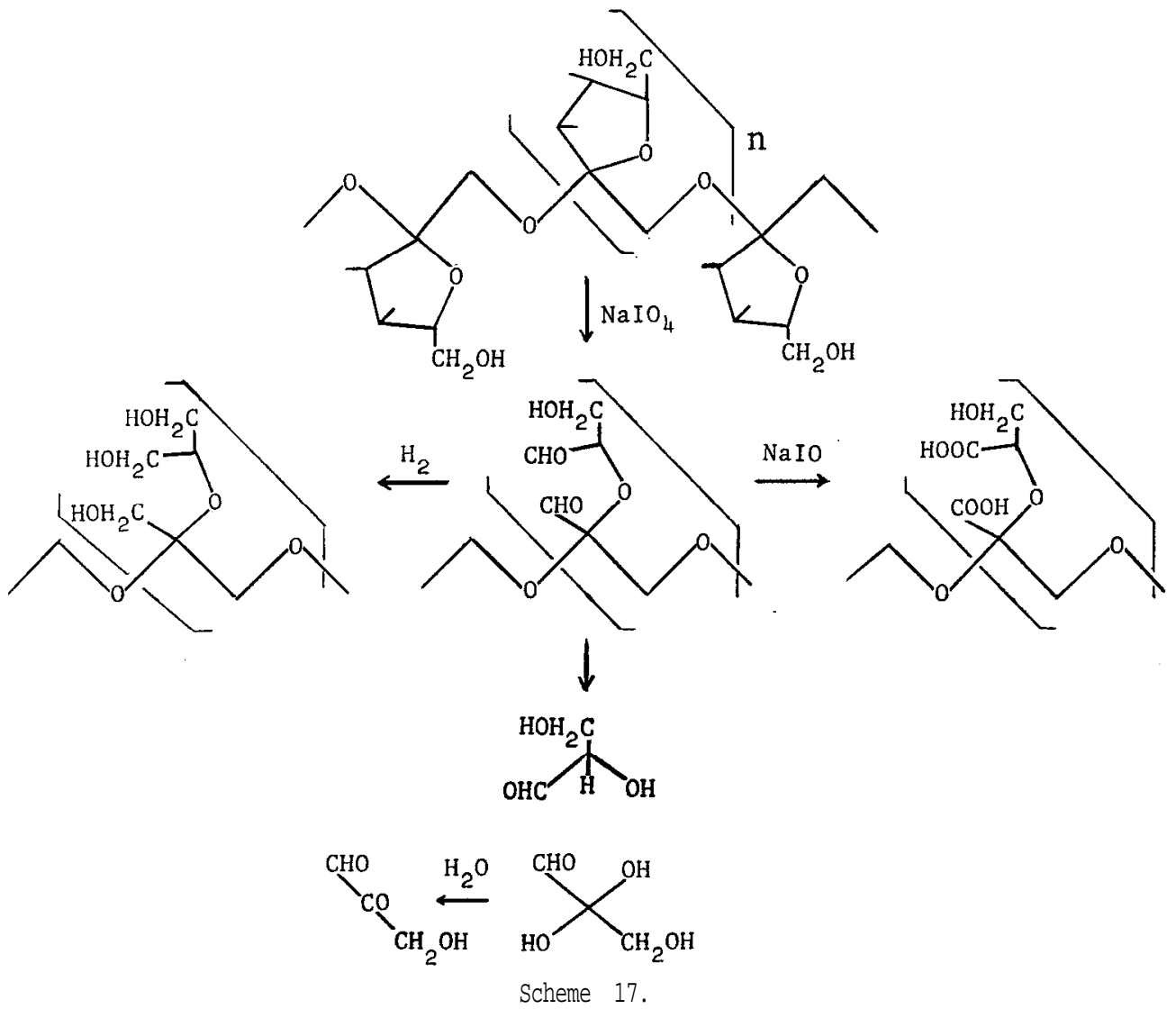


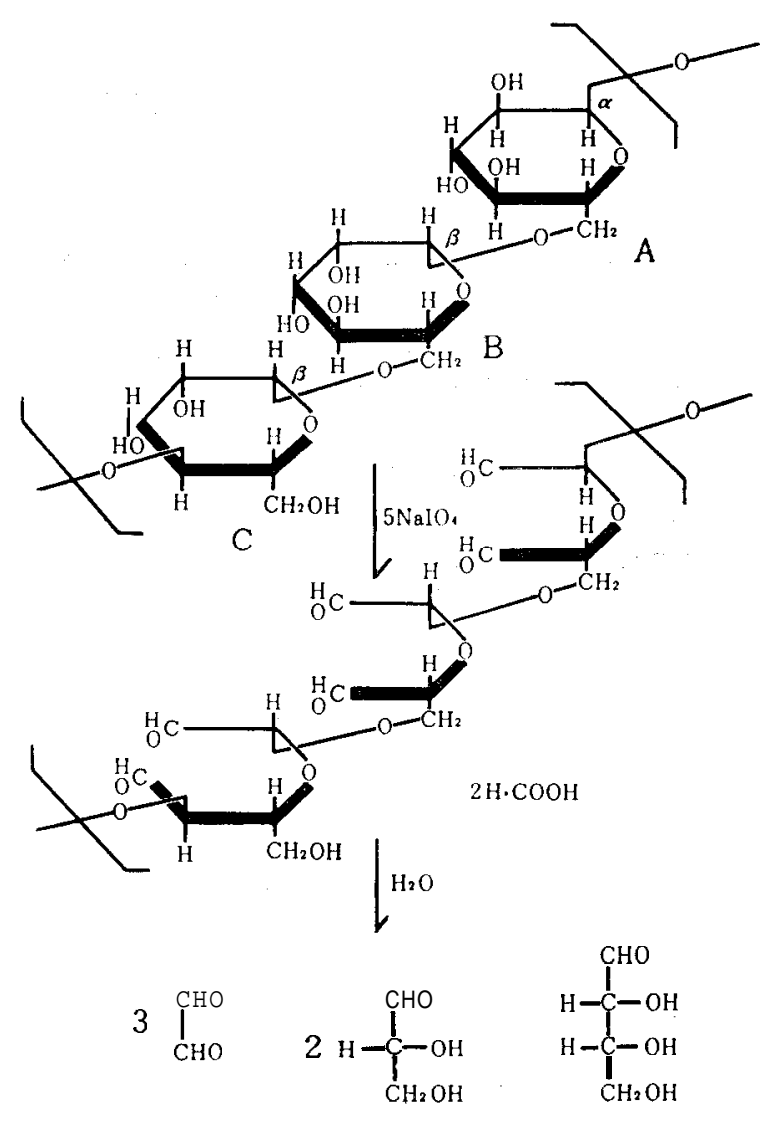

Scheme 18.

\section{iii. Mannan}

Konjak-glucomannan was subjected to glycol-scission. The consumption rate of periodate by glucomannan was affected by $\mathrm{pH}$ of the solution, and the optimum pH of that was 6. 7. But the final quantity of the consumption was equally 1.5 mole. Mannose was obtained in the ratio of $9.6 \%$ in the hydrolysate of oxidized Konjak-glucomannan besides glyccrinaldehyde, erythrose, etc. (Scheme 18). It would be proper to say that the position of glycosidic linkages are $1 \rightarrow 4$ and the branched chain structure (Smith and Srivastava, 1959). From the results of methylation, it seems that the molecule of Konjak-glucomannan branches on $\mathrm{C}-3$ of mannose constituting it.

\section{Derivatives}

\section{i. Derivatives obtained from oxidized starch}

Oxidized starch obtained by periodate oxidation was condensed with thiourea, then treated with alkyl halogenide to yield $S$-alkyl derivatives. Isothiourea derivatives thus obtained were coupled with amino acid derivatives. By the 


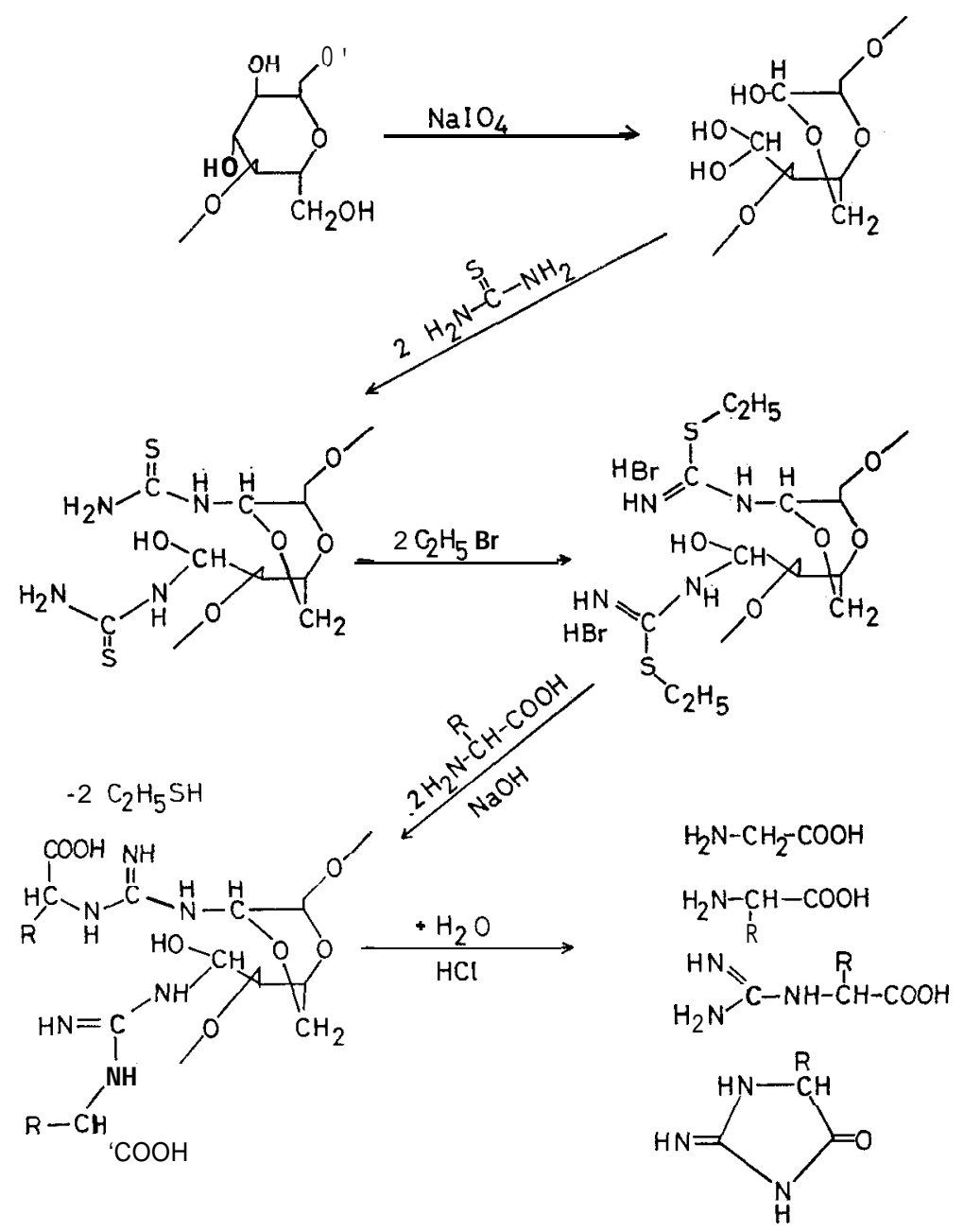

Scheme 19.

acid hydrolysis of the products, original amino acids, guanidino acids or their lactam and glycine in any case were recognized (Scheme 19).

ii. Nitro- and amino-polysaccharide formation from dextran

Dextran was subjected to oxidative scission by pcriodate, followed by ring closure with nitromethane to form nitrodextran. The nitro group attached to the ring was reduced by $\mathrm{LiAlH}_{4}$ to yield amino-polysaccharide of which the molecular weight was about 10,000 (Scheme 20). It became clear that nitrodextran consisted of 3-deoxy-3-nitro-mannopyranoside, -glucopyranoside, -galactopyranoside and -talopyranoside and their molar ratio was 6: 5: 1: 2 as determined by column chromatographic separation and gas chromatographic analysis of the methanolysate of nitro-dextran. 


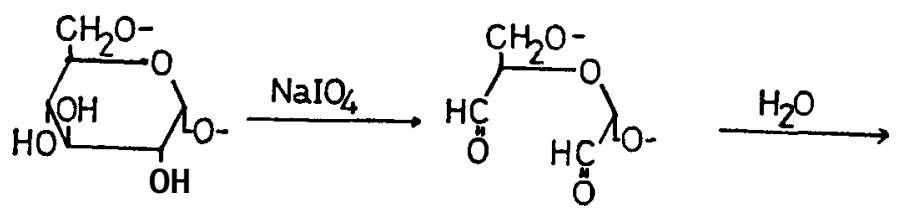

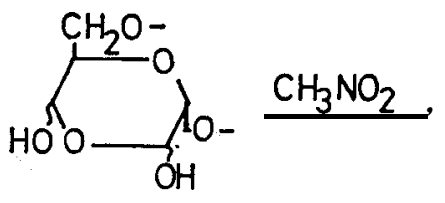

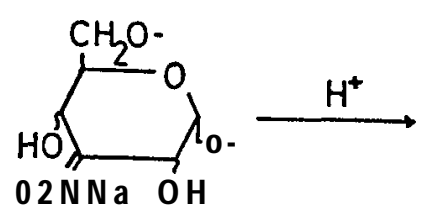

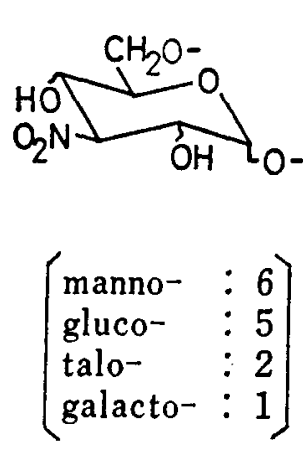
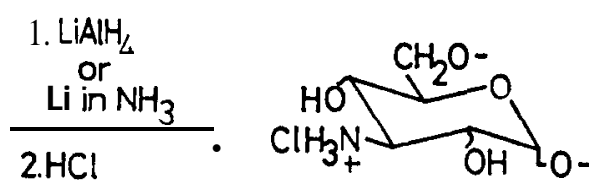

Scheme 20. Preparation of nitro- and amino-polysaccharides.

\section{iii. Triazine derivatives from polyuronic acids}

Incorporation of the carboxyl group of uronic acids and polyuronic acids into a triazine ring was studied. s-Triazine derivatives of polyuronic acids such as pectin and alginic acid were prepared similarly (Scheme 21). After hydrolysis, triazinylated monosaccharides were isolated and identified with authentic derivatives.

\section{iv. Glucosylthiourea}

Some devices were described in order to prepare this useful compound in pure state (Micheel and Berlenbach, 1952).

v. $I$ - $\left(N_{\alpha}-L\right.$-Argino $)-1$-deoxy- $\beta-D$-fructose and $1-\left(N_{\omega}-L\right.$-argino $)-1$-deoxy- $\beta-D$-glucose

From the reaction of $\mathrm{S}$-methylglucosylisothiourcn and ornithine the latter was obtained, whereas by heating of Arg and glucose in methanolic solution the former was obtained (Hamamura and Naito, 1956). (Scheme 22).

\section{vi. Reaction of basic amino acids with S-methylglucosylisothiourea}

Under the mild condition, histidine gave several derivatives which seem to be substituted at the different positions with glucosylamidyl group. E-Amino group of lysine reacted rapidly with the reagent, but a-amino group was scarcely reactive. The product, $\varepsilon$-glucosylamidyllysine was isolated by column chromatog- 
Methyl ester of pectin Methyl ester of alginic acid<smiles>C1CCCCC1</smiles>

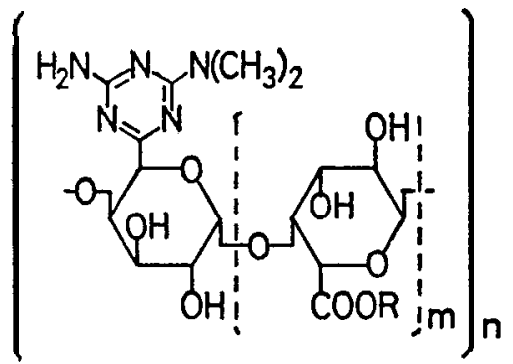

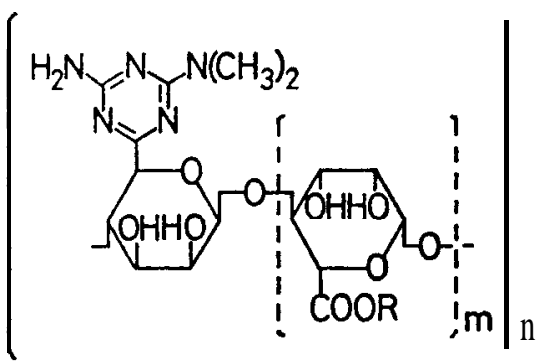

$\mathrm{R}:-\mathrm{H}$ or $-\mathrm{CH}_{3}$
(a) $m=1$
(b) $m=10$
(a) $m=1$
(b) $m=3$

$\mathrm{R}:-\mathrm{H}$ or $-\mathrm{CH}_{3}$

Scheme 21. Supposed structures of triazinylated pectin and alginic acid.

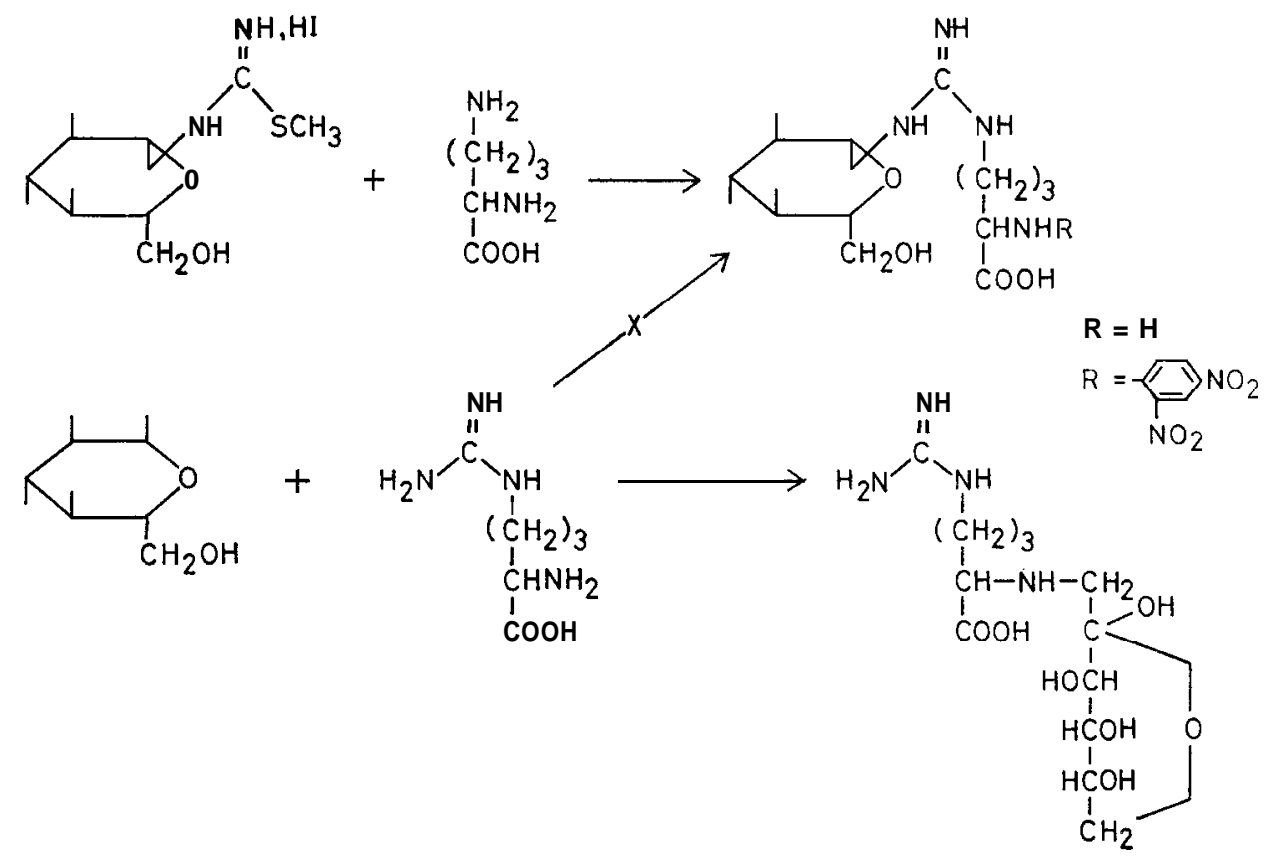

Scheme 22.

raphy employing Amberlite XE-60. Argininc also reacted with the reagent only at its $\alpha$-amino group to a slight extent: 


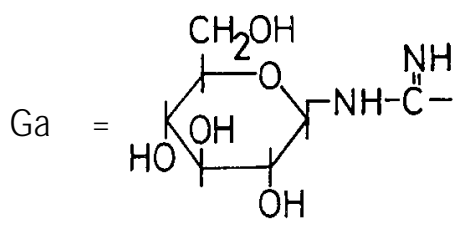<smiles>O=C(NC(Cc1[nH]cnc1Cl)C(=O)O)C1CCCCC1</smiles><smiles>NC(CCCCNC1CCCCC1)C(=O)O</smiles><smiles>O=C(O)C(Cc1cnc(Cl)[nH]1)NC1CCCCC1</smiles><smiles>N=C(N)NCCCC(Cl)C(=O)O</smiles>

\section{SECTION 111. ENZYME ANDPROTEIN CHEMISTRY}

\section{Periodate oxidation of protcin}

\section{Periodate number}

Proteins consumed a proper- amount of periodate dependingon the nature of protein, while the peptide linkage was nothing to do with this reaction (Fig. 1). Aldehyde and ammonia wereyiclded simultaneously (Martin and Synge, 1941) (Scheme 23). Therefore, it was thought thalnot only hydroxylysine, but also tryptophan, scrine, throonine and other amino acids composing peptidr might be clcaved in situ. This periodate consumption of proteins was termed as periodatc number.

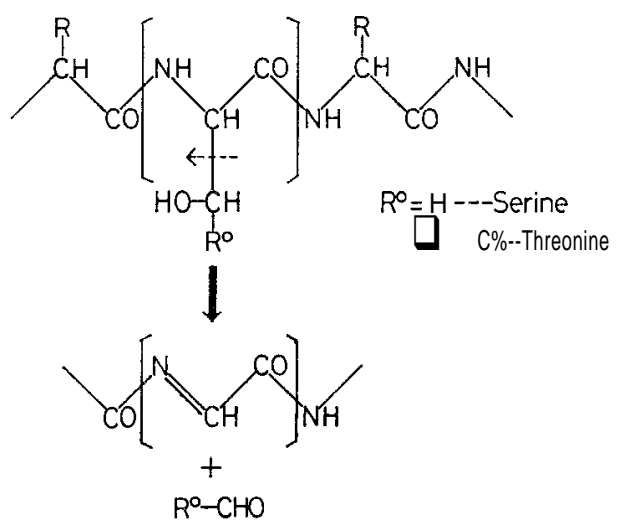

Scheme 23. 


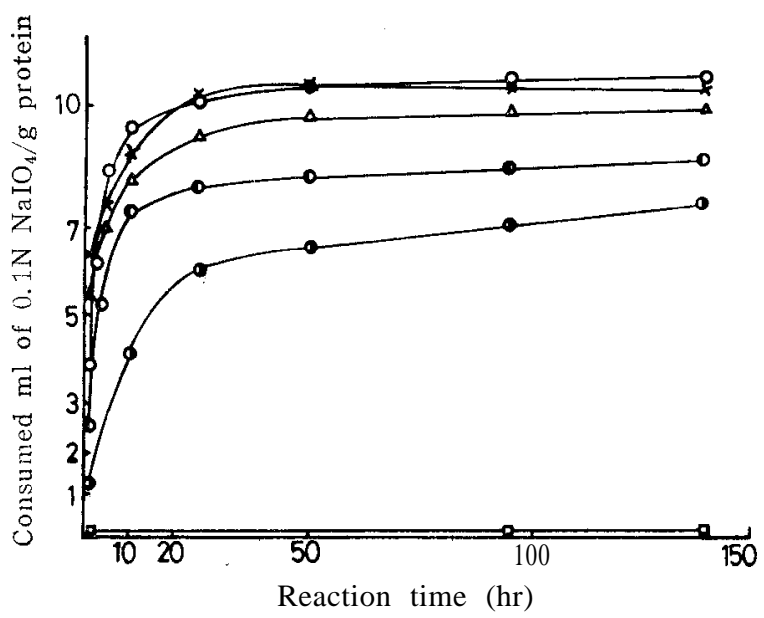

Fig. 1. $\bigcirc-O$ casein; $\times-X$ fibrin; $\triangle-\triangle$ edestin;

-1) gelatin; - fibroin; $\square$-u nylon.

\section{ii. W-Spectrum and periodate consumption}

Among amino acids, tryptophan consumed very rapidly periodate and the shape of UV-spectrum changed in parallel with it (Fig. 2), whereas the spec-

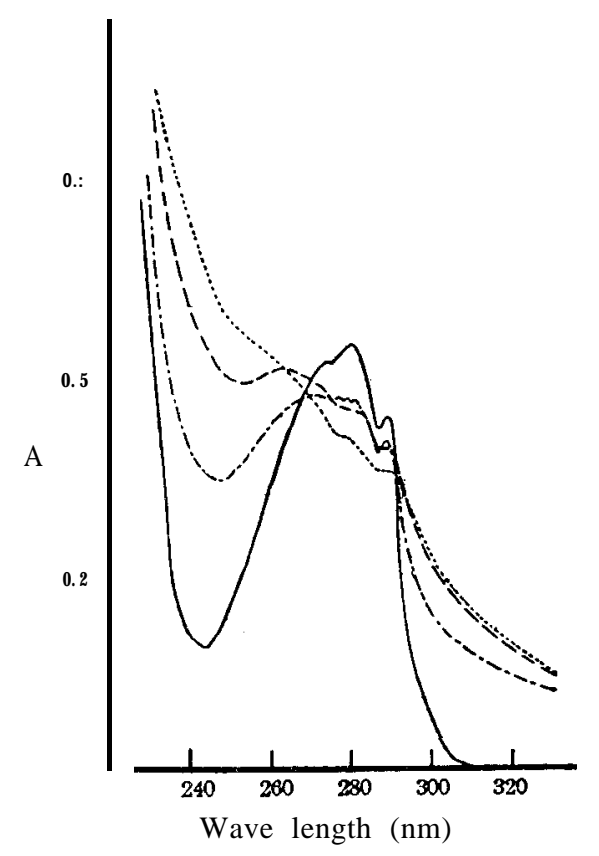

Fig. 2. UV-spectra of tryptophan and oxidized tryptophan. _- tryptophan ; .... oxidized tryptophan for $6 \mathrm{hrs}$ at $25^{\circ} \mathrm{C}\left(1.23 \mathrm{M} \mathrm{NaIO}_{4} / \mathrm{MTrp}\right) ;--$, oxidizeh tryptophan for $35 \mathrm{hrs}$ at $25^{\circ} \mathrm{C} ; \ldots \ldots$, oxidized tryptophan for $48 \mathrm{hrs}$ at $25^{\circ} \mathrm{C}$. 
trum of tyrosine changed slightly as shown in Fig. 3. Under the similar condition, other amino acids except cysteine did not consume periodate, if any.

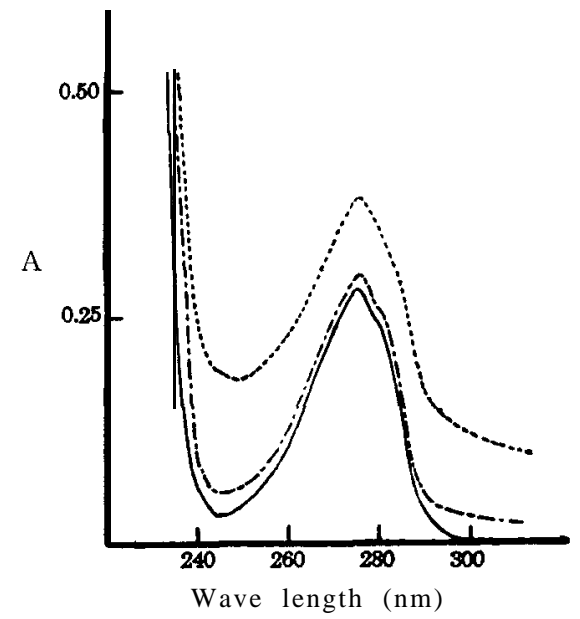

Fig. 3. UV-spectra of tyrosine and oxidized tyrosine. tyrosine oxidized for $76 \mathrm{hrs}$ at $25^{\circ} \mathrm{C} ; \ldots \ldots$. tyrosine oxidized for $20 \mathrm{hrs}$ at $25^{\circ} \mathrm{C}$.

\section{iii. Oxidation of bacterial a-amylase}

Bacterial a-amylase (Fukumoto, 1943) was oxidized by periodate under a mild conditon. The relation between consumption of oxidant and enzymatic activity was discussed. A completely oxidized enzyme had still some saccharifying activity and liquefying activity, while dextrifying activity was lost (Fig. 4).

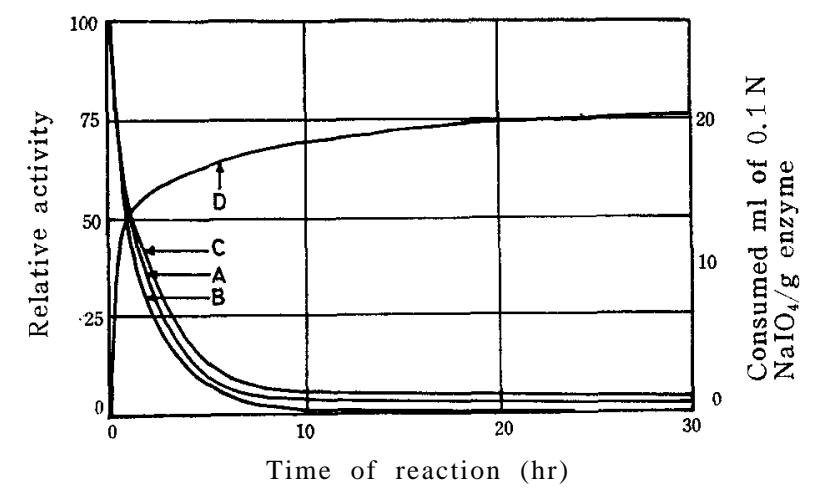

Fig. 4. Amount of periodate reduced by $\alpha$-amylase and diminution of enzymatic activities.

A, Liquefying activity; B, Dextrifying activity; C, Saccharifying activi-

ty ; D, Consumed $\mathrm{NaIO}_{4} / \mathrm{g}$ enzyme.

Antibody aginst oxi. - $\alpha$-amylase, is produced and this anti-serum shows precipitation with not only oxi. - $\alpha$-amylase, but also a-amylase. It was assumed 
that anti-serum, formed by sensitization with oxi. -a-amylase, combines with the active surfaces of $\alpha$-amylase and oxi. -a-amylase, to show precipitation,

iv. 0 xidation of ovalbumin

Ovalbumin was oxidized by periodate in various degrees, without coagulation (Desnuelle et al., 1947) (Fig. 5). Oxidized ovalbumin contained no more cysteine and tryptophan, but tyrosinr, histidine and cystine remained almost unchanged (Table 2).

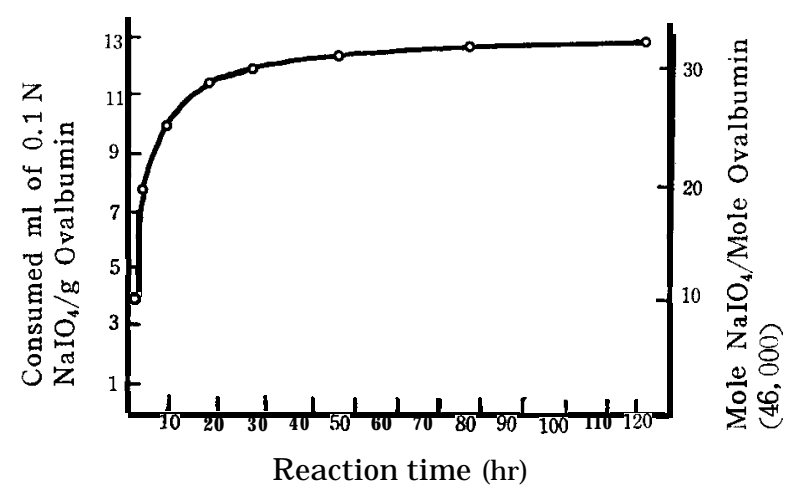

Fig. 5. Periodate oxidation of ovalbumin.

Table 2. Changing in composition caused by oxidation.

\begin{tabular}{|c|c|c|c|}
\hline Sample & a & b & c \\
\hline Degree of oxidation & $10 \mathrm{Mol} . \mathrm{NaIO}_{4}$ & $20 \mathrm{Mol} . \mathrm{NaIO}_{4}$ & $30 \mathrm{Mol} . \mathrm{NaIO}_{4}$ \\
\hline $\begin{array}{l}\text { Yield } \\
{[\alpha]_{\mathrm{D}}^{20},(\mathrm{pH} \text { H. }} \\
\text { tryphophan } \\
\text { Histidine } \\
H S- \\
\text { Arginine } \\
\text { Tyrosine } \\
\text { Cystine }\end{array}$ & $\begin{array}{r}90 \% \\
-55.5^{\circ} \% \\
0.2 \% \\
2.35 \% \\
0 \\
5.5_{0} \% \\
3.60 \% \\
1.1_{5} \%\end{array}$ & $\begin{array}{l}83 . \% \\
-55.5^{\circ} \% \\
0 \\
2.33 \% \\
\\
05.3 \% \\
3.32 \% \\
1.1_{1} \%\end{array}$ & $\begin{array}{l}64 \% \\
\mathrm{~m}-83.3 \\
0 \\
2.33 \% \\
0 \\
4.81 \% \\
3.0_{0} \% \\
1.1_{1} \%\end{array}$ \\
\hline
\end{tabular}

\section{v. Oxidation of pepsin}

About 30 moles of periodate react with 1 mole of pepsin. It is concluded that the lowering of the absorbance of UV-absorption is caused by decomposition of tryptophan, and this amino acid seems to play an important role to peptic activity (Fig. 6).

vi. Oxidation of trypsin

Considering together the changing of enzymic activity and the tendency of consuming $\mathrm{NaIO}_{4}$, it is deduced that trypsin possesses more groups which are slowly oxidized than pepsin and that these groups may contribute to the gelatin liquefaction (Fig. 7).

\section{vii. Oxidation of lysozyme}

Lysozyme oxidized under moderate conditions was obtained as crystals with 


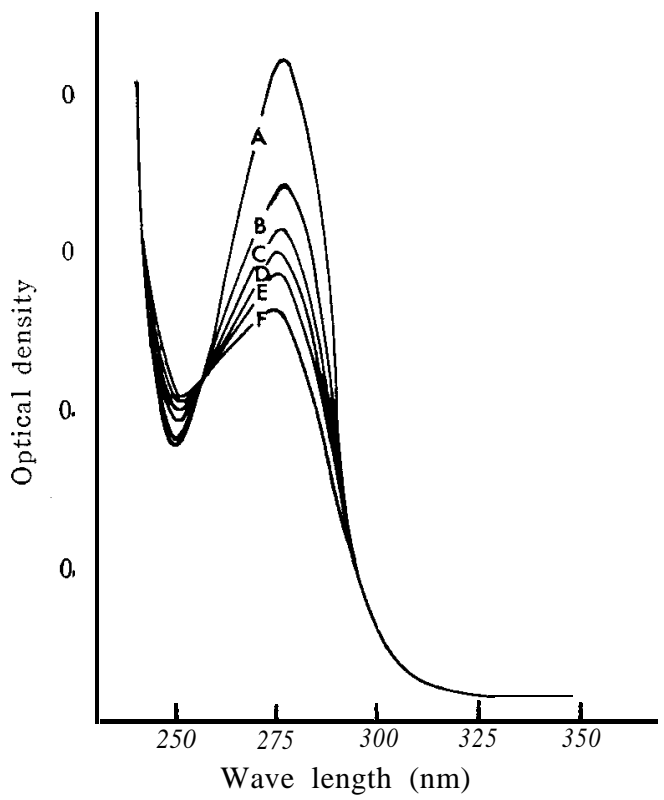

Fig. 6. Ultraviolet absorption of pepsin and pepsin oxidized in the mild condition. A, Native pepsin; B, 4 hrs oxidized pepsin; C, 21 hrs oxidized; $\mathrm{D}, 46 \mathrm{hrs}$ oxidized ; E, $70 \mathrm{hrs}$ oxidized ; F, just inactivated pepsin (hypothetical).

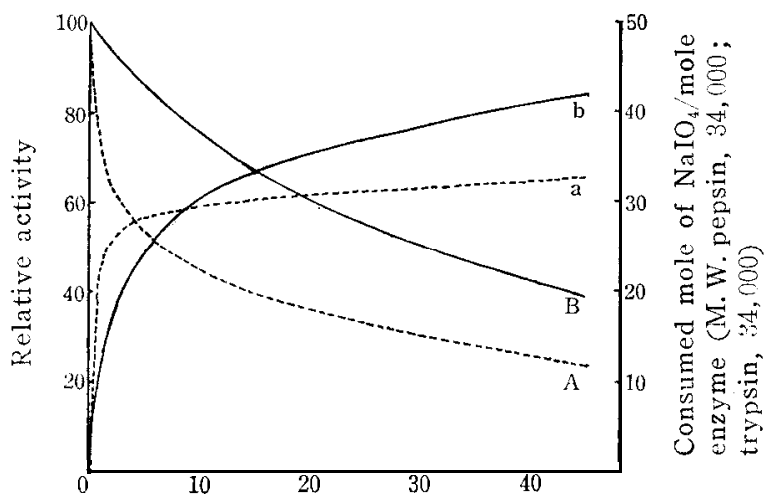

Hrs reacted with periodate

Fig. 7. Amount of periodate reduced by pepsin and trypsin and diminution of peptic and tryptic activity on haemoglobin substrate. A, peptic activity; B, tryptic activity; a, $\mathrm{NaIO}_{4}$ reduced by pepsin; b, $\mathrm{NaIO}_{4}$ reduced by trypsin.

$60 \%$ of the original activity (Fig. 8). The decrease in lytic activity has a linear relationship to the lowering of the optical density at $280 \mathrm{~nm}$ (Fig. 9). This lowering being caused chiefly by the decomposition of tryptophan, it may 


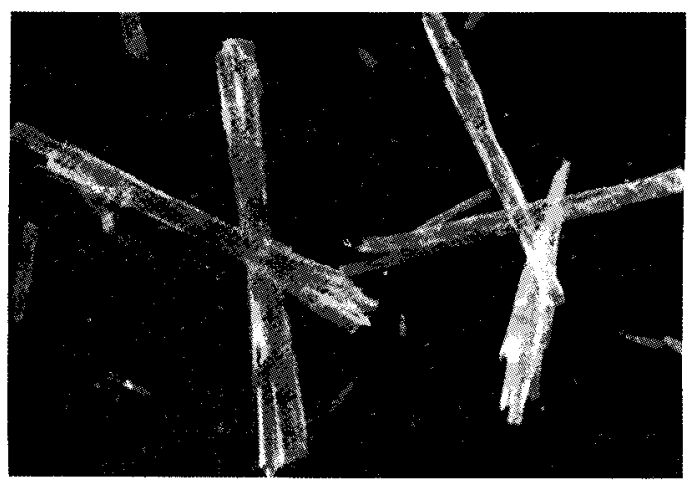

Fig. 8. Oxidized lysozyme (lytic activity: ca 60\%). ×330

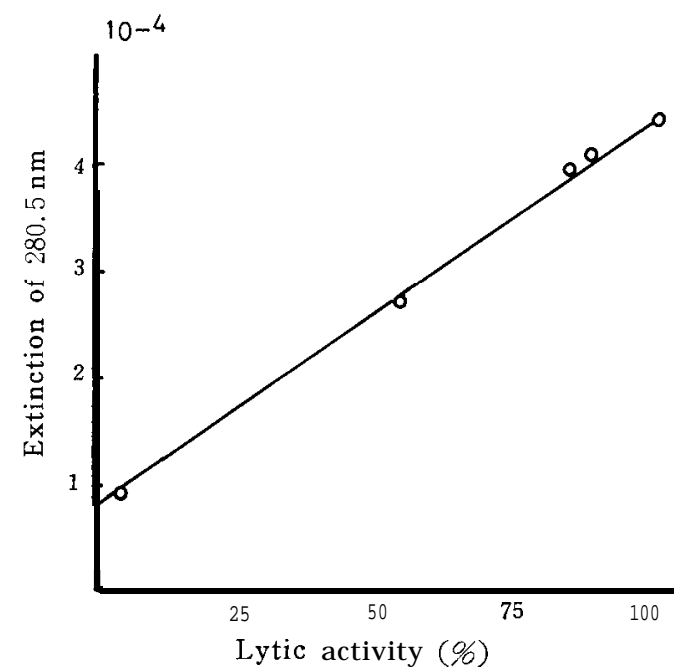

Fig. 9. Decrease of the extinction in UV-spectrum of lysozyme and decrease of lytic activity caused by oxidation.

be concluded that tryptophan residue seems to play an important role in lytic activity (Fraenkel-Conrat, 1950).

\section{Reaction with ethylene oxide}

It is already known that ethylene oxide reacts with several groups shown in Scheme 24 (Fraenkel-Conrat, 1944), however ethylene oxide reacted only with amino group of amino acid in alkali side under mild conditions, when magnesium ion was added.

i. Reaction with trypsin

One mole of trypsin combined with 10 moles of ethylene oxide at $5^{\circ} \mathrm{C}, \mathrm{pH}$ 8.0 in 12 days, but the change in the activity through combination was not plain (Table 3). 


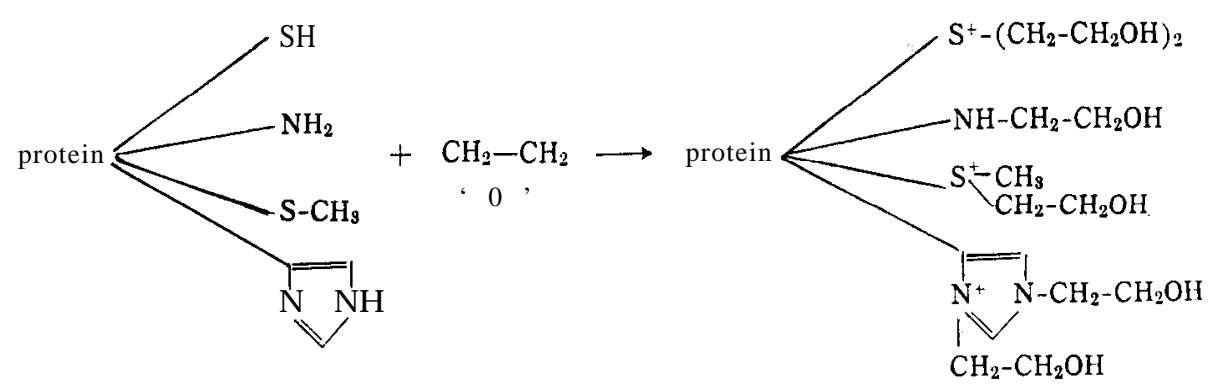

Scheme 24.

Table 3. Reaction of trypsin with ethylene oxide (EO).

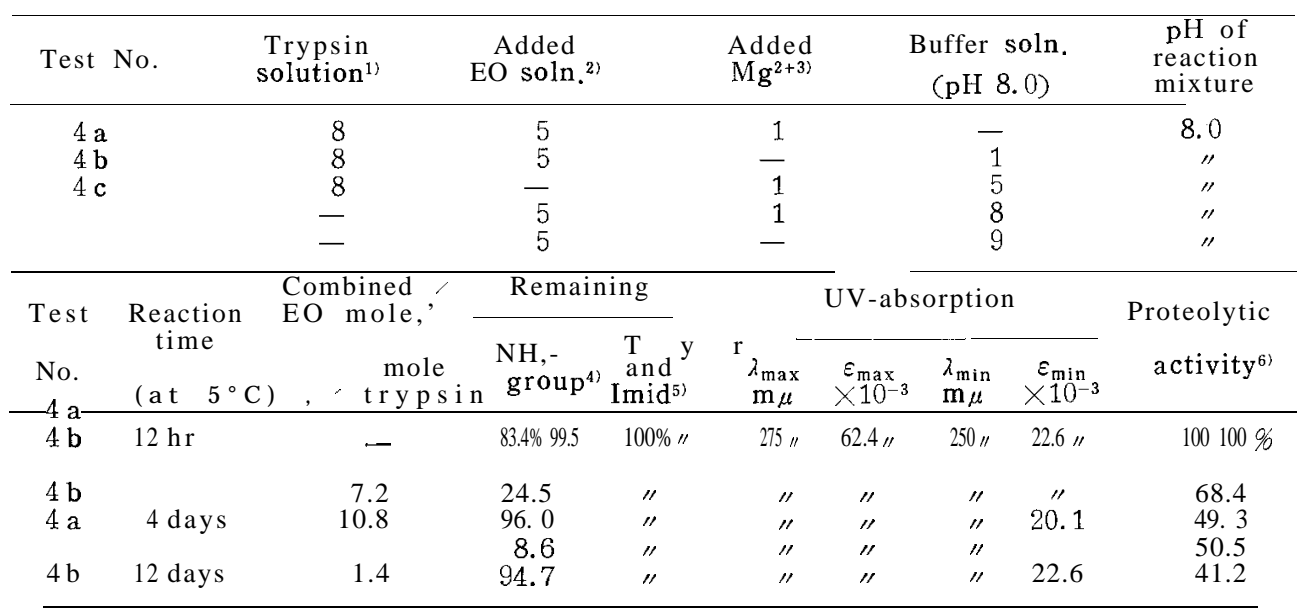

1) $200 \mathrm{mg}$ crystalline trypsin were dissolved with $25 \mathrm{ml} 0.05 \mathrm{MpH} 8.0$ phosphate buffer.

2) The solution contained $29.6 \mathrm{mg} \mathrm{EO} / \mathrm{ml}$.

3) The solution contained about $50 \mathrm{mg} \mathrm{Mg}^{2+} / \mathrm{ml}$ and adjusted to $\mathrm{pH} 8.0$.

4) Estimated by ninhydrin.

5) Estimated by Folin's phenol reagent.

6) Estimated by haemoglobin method.

\section{ii. Reaction with lysozyme}

One mole of lysozyme combined with 12 moles of ethylene oxide at $4-5^{\circ} \mathrm{C}, \mathrm{pH}$ 8.7, when magnesium ion existed. Lysozyme, after having reacted with ethylene oxide so thoroughly that amino groups were no more detectable, still did not alter in the lytic activity and UV-absorption (Schroeder, 1952). Only in the ionophoresis a different result appeared (Fig. 10). This N-hydroxyethyl derivative of lysozyme behaved almost equally with the native lysozyme in the oxidation by periodate (Tabe 4).

\section{Glucosylamidination and amidination}

An active glucosylamidyl derivative of trypsin was prepared by reacting 


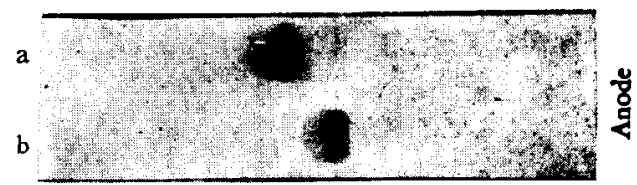

Fig. 10. Electrophoregram of EO-Lysozyme. a) Control (Native lysozyme) ; b) EO-lysozyme.

Michaelis N/10 tartarate buffer ( $\mathrm{pH} 4.0), 500$ Volt, 4.8-9.5 mA/4 cm, $3 \mathrm{hrs}$ $\mathrm{HgCl}_{2}-\mathrm{BPB}$ staining.

Table 4. Reaction of lysozyme with ethylene oxide (EO).

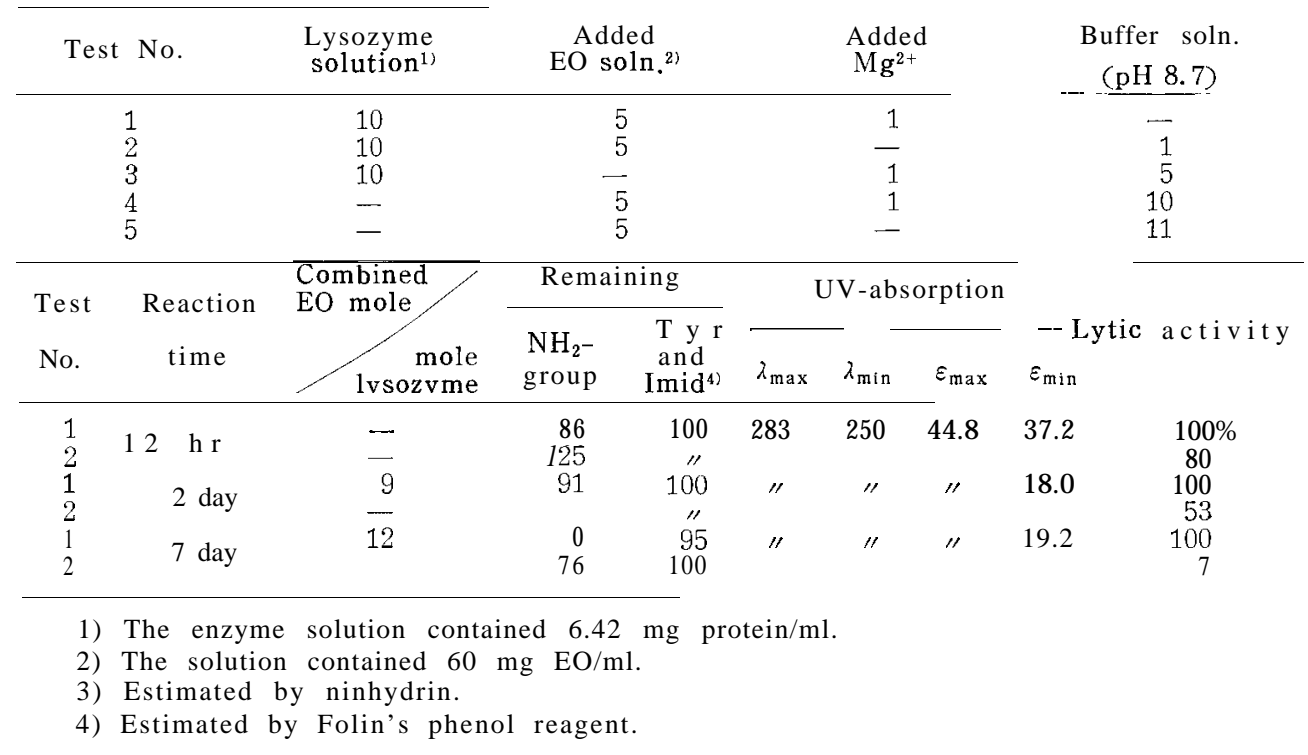

S-methylglucosylisothiourea with the native enzyme under alkaline conditions (Micheel and Herold, 1953) (Fig. 11). Chemical evidence is presented to show that modification of the enzyme has involved the glucosylamidination of the E-amino groups of 3 lysine residues and the imidazole rings of 3 histidine residues. Some of the physical and enzymic properties of the modified enzyme are discussed in relation to the properties and mechanism of action of trypsin.

By amidination of trypsin, the enzyme does not suffer the loss of the enzymatic activity, but becomes rather stable against the autodigestion (Terminiello et al., 1958).

By the reaction of trypsin and S-methylisothiourea, the guanidine group of enzyme derivative clearly increases. It is deduced that $\varepsilon$-amino group of lysine and other groups which are to be glucosylamidinated or amidinated have nothing to do with the tryptic activity (Table 5, 6). 


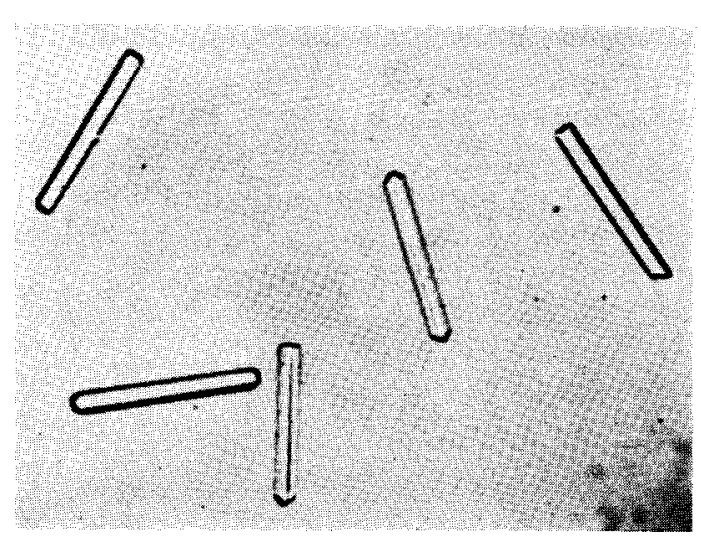

Fig. 11. Crystalline Ga-trypsin $(\times 225)$.

Table 5. Reaction of S-methylglucosylisothiourea and trypsin.

\begin{tabular}{|c|c|c|c|}
\hline \multirow{2}{*}{ Reaction time } & $\begin{array}{l}\text { Combined sugar } \\
\text { component }(\mathrm{mg})\end{array}$ & \multirow{2}{*}{$\begin{array}{c}\text { Relative activity } \\
(\%)\end{array}$} & \multirow{2}{*}{$\frac{\mathrm{NH}_{2}-\operatorname{group}(\mathrm{mol})}{\operatorname{protein}(\mathrm{mol})}$} \\
\hline & protein $(\mathrm{mol})$ & & \\
\hline $\begin{array}{l}24 \mathrm{hr} \\
48 " \prime\end{array}$ & $\begin{array}{l}3.3 \\
4.6 \\
5.7\end{array}$ & $\begin{array}{l}89 \\
78 \\
71\end{array}$ & 7.86 \\
\hline $\begin{array}{l}96 / \prime \\
6 \text { days } \\
14 " \prime \\
20 "\end{array}$ & $\begin{array}{l}6.0 \\
6.5 \\
6.5\end{array}$ & $\begin{array}{l}65 \\
58 \\
53 \\
53\end{array}$ & $\begin{array}{l}6.76 \\
6.07\end{array}$ \\
\hline
\end{tabular}

Table 6. Reaction of S-methylisothiourea and trypsin.

\begin{tabular}{ccccc} 
Reaction time & $\begin{array}{c}\text { Increase of } \\
\text { amidine group } \\
(\%)\end{array}$ & $\begin{array}{c}\text { Relative } \\
\text { activity } \\
(\%)\end{array}$ & $\begin{array}{c}\text { Relative activity } \\
\left.\text { (with } 0.01 \mathrm{M} \mathrm{CaCl}_{2}\right)\end{array}$ & $\begin{array}{c}\text { NH,-group (mol) } \\
\text { protein (mol) }\end{array}$ \\
\hline $24 \mathrm{hr}$ & 115 & 95 & 78 & 7.86 \\
$48 \prime \prime$ & & 94 & 68 & \\
$72 \mathrm{\prime \prime}$ & 190 & 94 & 57 & 6.92 \\
$963 \prime \prime$ & 220 & 93 & 49 & \\
15 days & & 92 & 38 & \\
\hline
\end{tabular}

\section{SECTION IV. ALLERGEN FOR FASCIOLIASIS}

\section{Proteinic allergen}

From liver flukes (Fasciola hepatica) and a culture medium of them a proteinic allergen was isolated in crystalline form by means of various fractionations (Fig. 12). This preparation showed a specific and sharp skin reaction against cattle bearing Fasciola hepatica. The composition was as follows:

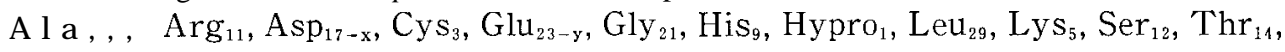
Trp,, Tyr,, $\mathrm{Val}_{18}$, Amide,,; $\mathrm{x}+\mathrm{y}=13$. 


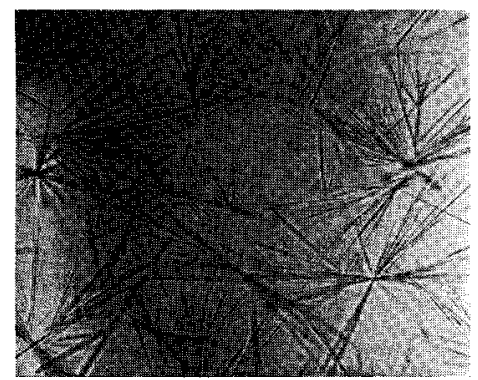

Fig. 12. Microphotogram (X300) of proteinic allergen for Fascioliasis.

\section{Allergen composed of RNA and peptide}

Another allergic substance was also isolated. This preparation is composed of ribonucleic acid $(95 \%)$ and a small amount of peptide (4.6\%). The RNA consists of nearly equal parts of adenylic, guanylic, uridylic and cytidylic acids, and the peptide is made up of $\mathbf{1 2}$ amino acids (14 mole). The allergen has no terminal nitrogen. However, when it was incubated in dilute alkaline solution, there was produced 1.5 mole of amino nitrogen per $100 \mathrm{~g}$ atom phosphorus. It seems that this amino group was derived not from the hydrolysis of the peptide bond, but from the cleavage of the more labile linkage. Therefore, the peptide presumably is connected through some labile linkage with some part of the polynucleotide, e.g. $2^{\prime} \mathrm{C}$ or $3^{\prime} \mathrm{C}$ of ribose, or phosphate.

Considering the instability in alkaline solution, a phosphoramide-linkage is more probable than a C-N linkage.

When the dilute alkaline solution of DNP-allergen is allowed to stand in the dark, its biological activity is lost, the nucleotide, peptide and DNP-OH content increases gradually: the absorbance at $360 \mathrm{~nm}$ also increases, the $\varepsilon(\mathrm{P})$ at the maximum has a value of 1,090. From this fact it was inferred that 7.2 mole of DNP-group was bound to $100 \mathrm{~g}$ atom of phosphorus. Molar ratio of $\mathrm{P}$ : amino acid is 1: 0.207. Hence, molar ratio of $\mathrm{P}: \mathrm{DNP}-\mathrm{OH}:$ amino acid : terminal amino acid is 67: 4.8: 14: 1 . From the sedimentation constant, the molecular weight was estimated roughly to be $20,000-30,000$. From this it follows that there is one terminal amino acid in the whole molecule of the original allergen. One molecule of DNP-allergen consisted of $67-70 \mathrm{~g}$ atom of phosphorus, 5 mole of DNP, and 14 mole of amino acids. Then, the molecular weight of allergen amounts to $25,000-26,000$, which is in accord with the results of ultracentrifuging.

Imd-DNP-His and a-DNP-His, besides $\varepsilon$-DNP-Lys, were identified in the acid hydrolysate of the DNP-derivative prepared from the allergen decomposed by alkali. Of these DNP-amino acids, a-DNP-His was recognized as the N-terminal of the peptide moiety that had newly arisen by alkali scission.

A DNP-peptide-nucleotide complex was isolated from the enzymatic hydrolysate of DNP-allergen. From the hydrolysate of this compound, adenylic acid, $\mathrm{DNP}-\mathrm{OH}$ and a peptide were identified. Since this adenylic acid is negative towards the periodate-benzidine reaction, it seems that this acid may be adeno- 
sine-3'-phosphate. The fact that no other nucleotide than adenylic acid could be detected suggested the peptide to be bound to the terminal nucleotide. On the whole, it appears that the peptide is bound to the terminal adenosine-3'-phosphate through its terminal amino acid (histidine) by a phosphoramide linkage. These results were illustrated as follows (Scheme 25) :
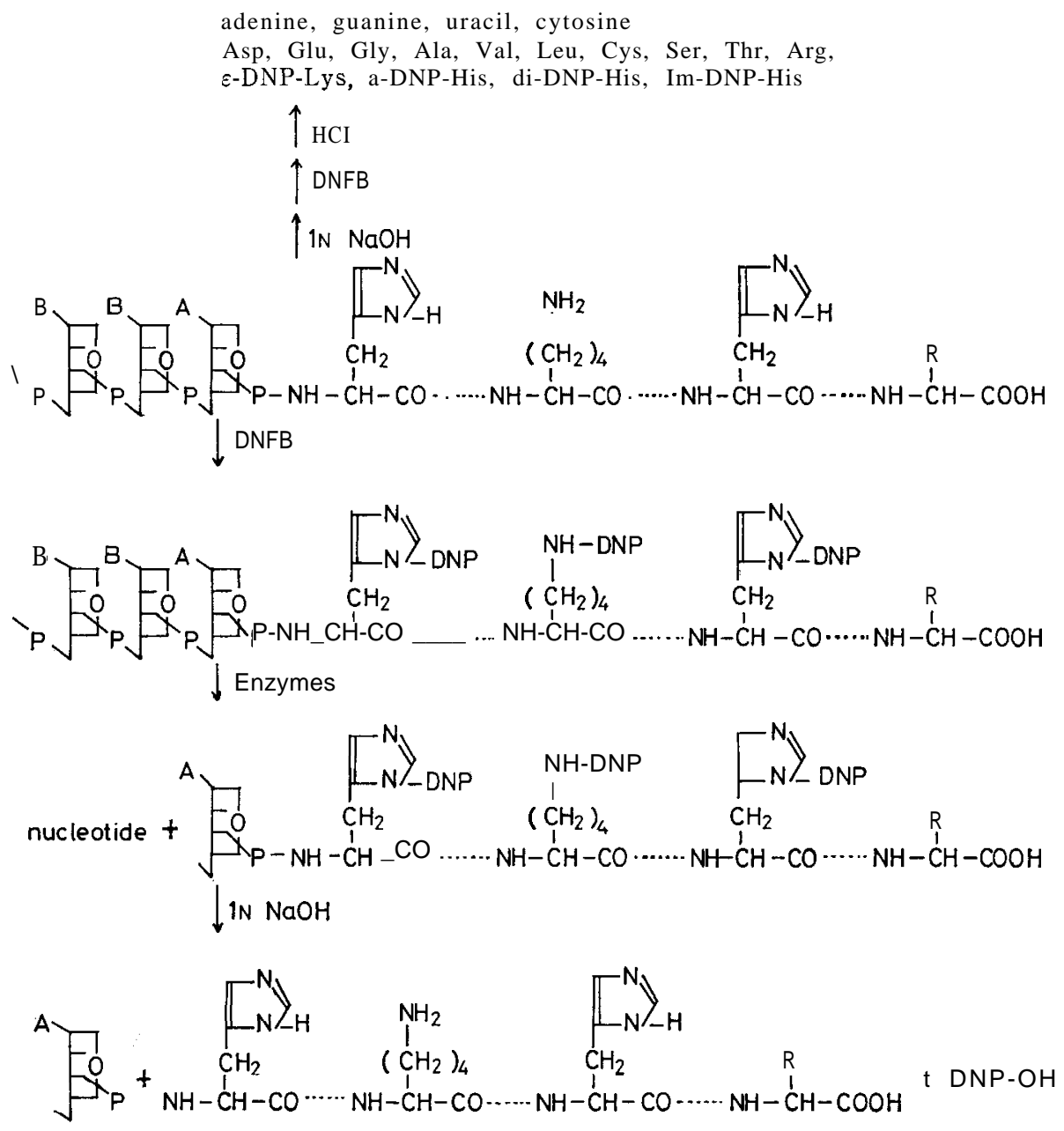

Scheme 25. Supposed structure of the allergen $\mathrm{P}$ and scheme of reactions.

A, adenine ; B, purine or pyrimidine base ; DNP-OH, 2,4-dinitrophenol.

\section{Precipitin}

Furthermore, another fraction was obtained from insoluble part (in phenol) of the extract of Fasciola hepatica. This fraction was still impure, but glycogenlike carbohydrate, and showed strong precipitin reaction with blood of cattle bearing Fasciola hepatica. 


\section{SECTION V. REPRESSION OF PROPAGATION OF TUMORS}

\section{By means of attenuating tumor cells}

i. Ehr. RNA and MA complex

RNA obtained from Ehrlich ascites tumor cells (Fig. 13), yeast, rice bran, and soy beans, and derivatives of RNA, as well as their complexes formed with some basic polymers, were examined to evaluate the effectiveness in inhibiting tumors. RNA complexes formed with a certain basic polymer were effective to some extent. By means of the pre-inoculation of tumor cells properly treated with such an RNA complex, the incidence of the tumor was inhibited completely in the challenge inoculation (Fig. 14).

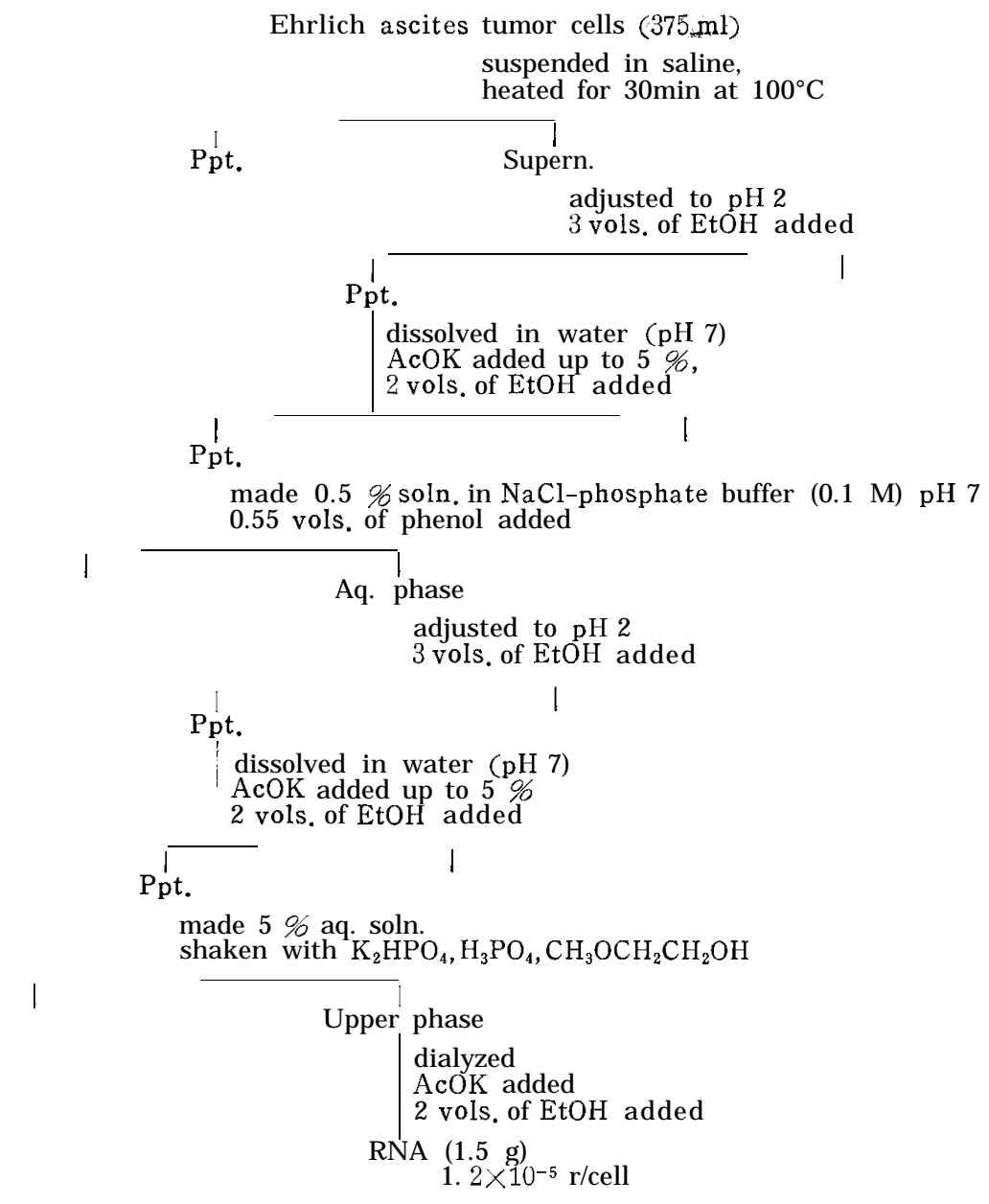

Fig. 13. Isolation of the RNA fraction from Ehrlich ascites tumor cells. 


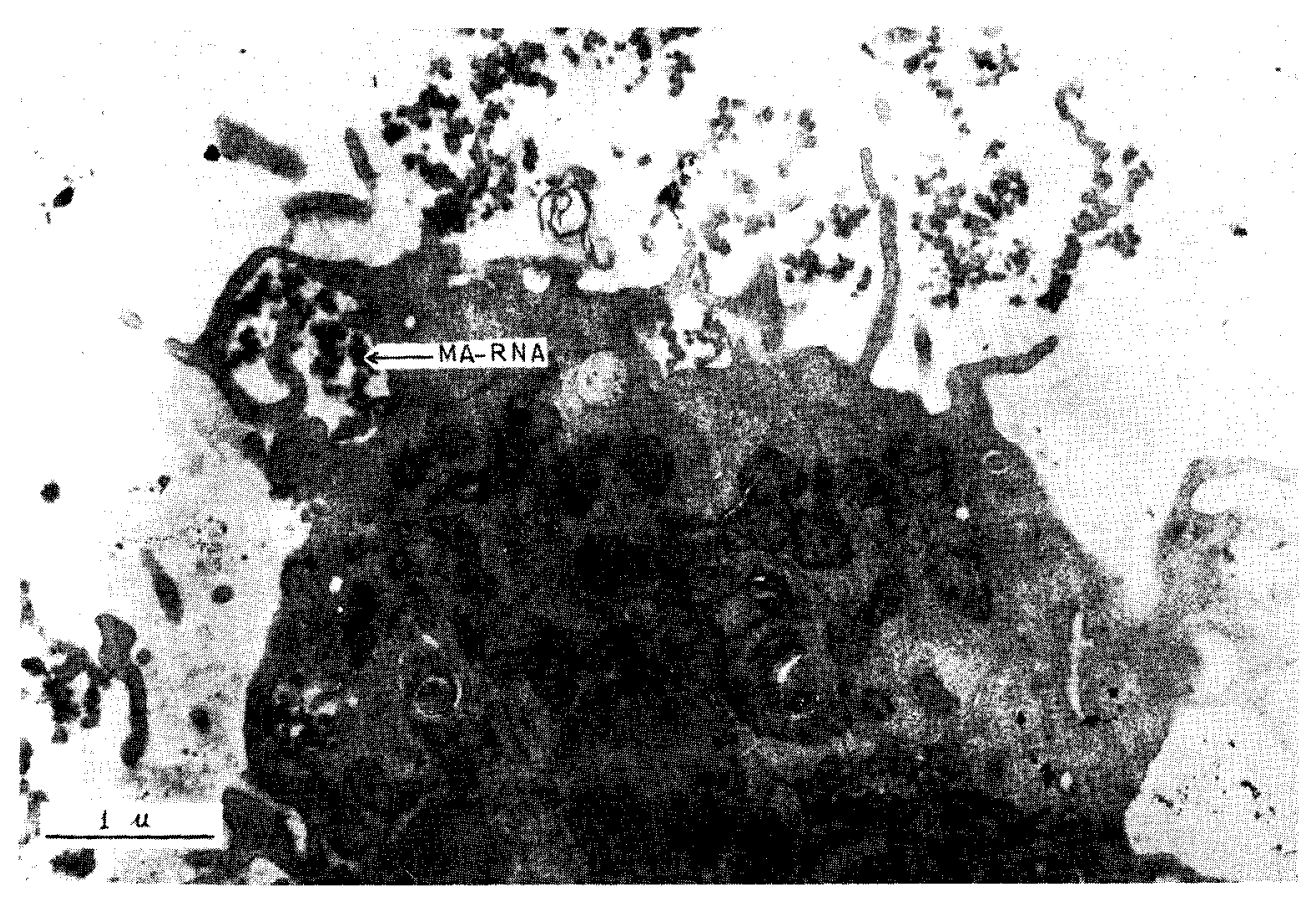

Fig. 14. MA-RNA complex is taken into the tumor cell $(\times 17000)$.

Table 7. Effectiveness of RNA's obtained from various sources and of combining moieties.

\begin{tabular}{|c|c|c|c|}
\hline Sample & $\begin{array}{l}\text { Ratio } \\
(w / w)\end{array}$ & $\begin{array}{c}\text { Mean Survival } \\
\text { day }\end{array}$ & $\mathrm{S} / \mathrm{T}^{3}$ \\
\hline Ehr. RNA & & 10 & $0 / 10$ \\
\hline Yeast-RNA & & 10 & $0 / 8$ \\
\hline Rice bran RNA & & & $0 / 8$ \\
\hline Soy bean RNA & & 10 & $0 / 8$ \\
\hline $\mathrm{MA}$ & & 16 & $0 / 10$ \\
\hline Ehr RNA: MA & $1: 2.77$ & survived & $8 / 8$ \\
\hline Yeast-RNA : MA & $1: 3$ & 17 & $0 / 8$ \\
\hline Rice bran RNA: MA & $1: 2.3$ & 10 & $\begin{array}{l}0 / 8 \\
0 / 8\end{array}$ \\
\hline Ehy. IREAA: RCAA: $400 \mathrm{~A}$ & $1: 3.24$ & 45 & $0 / 8$ \\
\hline Ehr. RNA: MC & $1: 2.5$ & 26 & $2 / 8$ \\
\hline Ehr. RNA treated with EDC ${ }^{2}$ & 90 mole $/ 100 \mathrm{P}$ & 18 & $0 / 8$ \\
\hline
\end{tabular}

1) Methylglycolchitosan (Senju, 1962).

2) $\mathrm{C}_{2} \mathrm{H}_{5}-\mathrm{N}=\mathrm{C}=\mathrm{N}-\mathrm{CH}_{2}-\mathrm{CH}_{2}-\mathrm{CH}_{2}-\mathrm{N}-\left(\mathrm{CH}_{3}\right)_{2}$

3) No. of survivors/no. of test mice.

The results obtained are summarized in Table 7. Namely, Ehr. RNA, yeast RNA, rice bran RNA, and soy bean RNA were by themselves not effective in repressing the tumor. On the other hand, complexes formed with cationic polymer were effective to some extent. Especially, mice treated with the complex of ionic exchanger CG-400 and Ehr. RNA survived relatively longer. The 
complexes of MA (Mandell and Hershey, 1960) and RNA's isolated from other sources than yeast had no effect on the tumor repression.

ii. $y$-RNA and MA complex

However, by means of aippropriately treating, Ehr. RNA was replaced by yeast RNA without any loss of the effectiveness as follow. Ehrlich tumor cells $\left(10^{5}\right)$ suspended in ascitic fluid (diluted appropriately with ascitic fluid of other mice) and the complex of yeast RNA : MA were mixed as shown in Table 8, then inoculated into the abdominal cavity of mice, after they had been incubated at $25^{\circ} \mathrm{C}$ for $20 \mathrm{~min}$.

Table 8. Repression of incidence of Ehrlich ascites tumor cells by mears of yeast RNA : MA treatment.

\begin{tabular}{|c|c|c|c|c|c|c|c|c|}
\hline \multirow{2}{*}{ Group } & \multicolumn{4}{|c|}{ Pretreatment } & \multicolumn{4}{|c|}{ No. of survivors/ no. of test mice } \\
\hline & $\begin{array}{l}\text { No. } \\
\text { cells-+ }\end{array}$ & $\begin{array}{c}\text { I-east RNA : } \\
\text { MA" }^{\prime \prime}\end{array}$ & Temp. & $\begin{array}{l}\text { Time } \\
\text { (min.) }\end{array}$ & pretreat & $\begin{array}{l}\text { 2nd } \\
\text { pretreat }\end{array}$ & $\begin{array}{l}\text { Challenqe } 2 \\
\text { inoculation }\end{array}$ & $\begin{array}{l}\text { 2nd challenge } \\
\text { 3) inoculation }{ }^{4}\end{array}$ \\
\hline$Y--R$ & $10^{5}$ & $0.16 \mathrm{mg}$ & $25^{\circ}$ & 20 & $0 / 12$ & - & - & - \\
\hline$Y-b$ & $10^{5}$ & 0.8 & & 20 & $7 / 12$ & & $5 / 7$ & $5 / 5$ \\
\hline$Y-C$ & $10^{\prime \prime}$ & & $\begin{array}{l}25^{\circ} \\
25^{\circ}\end{array}$ & 20 & $12 / 12$ & $\overline{11 / 1}$ & $7 / 12$ & $7 / 7$ \\
\hline$Y-\phi$ & $10^{\prime \prime \prime}$ & 6 & $25 \%$ & 20 & $12 / 12$ & $12 / 12$ & $32 / 12$ & $\begin{array}{l}11 \\
12 / 12\end{array}$ \\
\hline$M-C$ & $10^{55}$ & $3 \mathrm{mg} \mathrm{MA}$ alone & e $25^{\circ}$ & 5 & $12 / 12$ & & $0 / 12$ & \\
\hline
\end{tabular}

1) Yeast RNA :MA=1: 3 (by weight).

2) The 2nd pretreatment was performed on 10 th day after the 1 st pretreatment.

3) Challenge inoculations (1.0 cells) were carried out on 22nd day (a, b, c) or 12th day (d, e) after the last pretreatment.

4.) The 2nd challenge inoculation was carried out a half year after the 1.st challenge inoculation.

The challenge inoculation of tumor cells $\left(10^{5}\right)$ was carried out on the 22nd day after the treatment. As shown in Table 8, mice of the Y-c group did not develop any tumor as a result of the pretreatment, but some of them died after the challenge inoculation. In the Y-a group, the attenuation was insufficient, i.e., as tumor cells were sufficiently active, the pretreatment reached substantially the same results as inoculation of tumor cells. Mice of the Y-d group were inoculated with tumor cells attenuated with $6 \mathrm{mg}$ of yeast RNA: MA complex for $5 \mathrm{~min}$ at $25^{\circ} \mathrm{C}$. After the first pretreatment, one of the 12 mice developed a tumor, but the rest did not develop tumors. Mice of $\mathrm{Y}$-e group which were pretreated with $6 \mathrm{mg}$ of the complex at $25^{\circ} \mathrm{C}$ for $20 \mathrm{~min}$ did not develop any tumors in either of the two pretrcatments, or in the challenge inoculation. Furthermore, the second challenge inoculation was carried out half a year after the first challenge inoculation, On the whole, it was concluded that the yeast RNA as well as the Ehr. RNA is useful in developing cells enough to elicit the antitumor factor.

iii. $y$-RNA and imogolite complex

Furthermore, a clay mineral bearing cationic charges as basic polymer in lieu of MA was effectively applied as the combining moiety.

In this case the combination will probably occur between $\mathrm{AlOH}_{2}^{+}$of the clay and PO; of RNA (Fig. 15). By this combination, the digestion of RNA 
by nuclease will be hindered. The hydrolysis by RNase actually decreased by about $4 / 5$ at the combining ratio of clay: RNA $=4.4: 1$. The RNA combined with the clay may be taken into tumor cells, which are then attenuated.

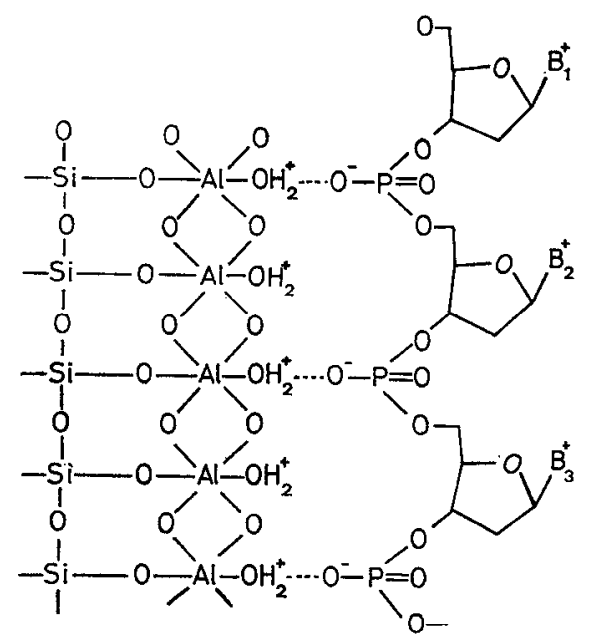

Fig. 15. Supposed structure of imogolite (Wada and Yoshinaga, 1969):

RNA complex.

iv. $y$-RNA and AEA (or AEC) complex

Aminoethyl ether of amylose (AEA) and aminoethyl ether of glycol cellulose (AEC) (Higuchi et al., 1970) in which the degree of polymerization was about 20-25 were mixed respectively with yeast RNA to produce stable complexes. The complexes dissociated about $5 \%$ at $\mathrm{pH} 4$ (Straumfjord and Hummel, 1959), while they were almost insoluble at neutral $\mathrm{pH}$. The complexes were hydrolyzed about by half by pancreatic RNase A. When Ehrlich ascites tumor cells were incubated with these complexes, the transplantability of those cells in mice were almost completely abolished. The mice pretreated thus became strongly resistant to a challenge inoculation afterwards. The effectiveness of AEA and AEC as a combining moiety was similar.

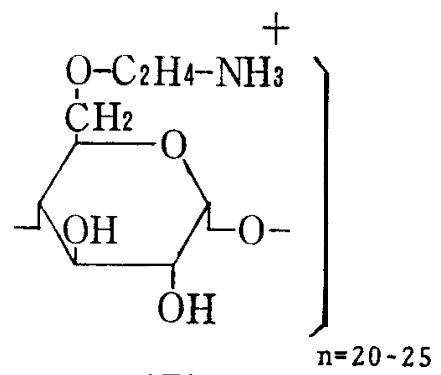

AEA

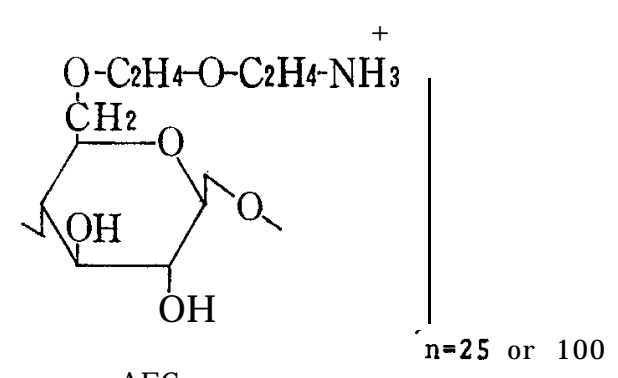

AEC

AEA and AEC as combining moieties. 


\section{Antitumor activity of some pseudopurines}

Some pseudopurincs were synthesized and examined for their biological activities, especially the anti-tumor activity of $1,3,4$-thiadiazolo $[3,2-a]$ pyrimidine and $s$-triazolo $[1,5-a]$ pyrimidine derivatives. The results showed that substituent groups at the 2-position of 1,3,4-thiadiazolo[3,2-a] pyrimidine played an important part in revealing cytocidal activity.

Strong activity was revealed by derivatives with electrophilic substituents (e.g., Cl, alkylsulfoxide, alkylsulfone) in the 2-position. The activity was enhanced with shorter alkyl groups. Ethanesulfonyl-7-methyl-5H-1,3, 4-thiadizolo[3,2-u] pyrimidin-5-one (XVII) strongly inhibited ${ }^{3} \mathrm{H}-\mathrm{Ur}$ or ${ }^{3} \mathrm{H}-\mathrm{Tdr}$ incorporation into RNA or DNA synthesis. That is, XVII in $40 \mathrm{ppm}$ inhibited $70 \%$ of RNA synthesis, $25 \%$ of DNA synthesis, but did not inhibit "II-Ur incorporation into E-cells and thymidine kinase at all. Finally, it is concluded that XVII was an antimetabolite for RNA polymerization, and the inhibition of DNA synthesis was attributable to the result of that of RNA synthesis.

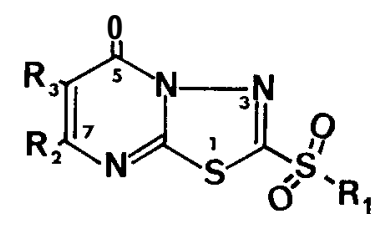

XVII

\section{SECTION VI. OTHERS}

\section{Analytical methods}

$i$. Estimation of furfural and other furan derivatives

Bromate-bromide method, hypoiodite method and a new method based on the ring-cleavage of furanwere described. Namely, the furan-ring is decomposed by bromine vapour to measure increased reducing power.

ii. Estimation of lysine

This method is concerned with the separation and determination of lysine from protein hydrolysates by means of paper ionophorcsis. In regard to the separation and the recovery of lysine, the following conditions were found suitable : current, $3.5 \mathrm{~mA} / 4 \mathrm{~cm}$ (width) ; voltage, 300 volts ; duration, $180 \mathrm{~min}$; electrolyte, $0.05 \mathrm{M} \mathrm{Na}_{2} \mathrm{CO}_{3}$ solution. Under the present experimental condition, the decomposition rate of lysine was estimated during ionophoresis, and data for the determination of lysine was given.

iii. Contribution to gas chromatography of natural products

About 200 compounds (mainly esters) was isothermally gas chromatographed under same conditions as possible by using 2 different columns of PEG-6000 and Apiezon L respectively. The following relationship was elucidated from results of the settled experiment. 
$\log \left(\log \mathrm{R}_{V}\right)=$ variable+O. 0015x boiling point

The variable was estimated in Apiezon L from electron-polarizability/unitvolume and intermolecular attracting force. In PEG-6000 column, the variable may be calculated from the strength of hydrogen bond between PEG and solute molecules, together with the value estimated from electron-polarizability.

iv. New method for carboxyl-terminus determination of peptides

A new and simple method for the determination of the C-terminal groups of peptides is proposed. The carboxyl groups are converted into the corresponding peptide-triazines by treating with dimethylbiguanide. These derivatives are then hydrolysed by Streptomyces griseus protease and the amino acid derivatives in the hydrolysate are identified by thin-layer or paper chromatography.

II. Controlled-release pesticides

\section{i. Synthesis of cellulose-6-(diethyl phosphorothioate)}

Phosphorylation of $1,2,3,4$-tetra-o-acetyl- $\beta$-D-glucopyranose was carried out with diethyl phosphorochloridothioate to prepare $1,2,3,4$-tetra-o-acetyl- $\beta$-D-glucopyranose-6-(diethyl phosphorothioate). Cellulose-6-(diethyl phosphorothioate) was also prepared by the reaction with sodium cellulosate and diethyl phosphorochloridothioate. By means of periodate oxidation, the phosphorylated position in anhydroglucose unit of cellulose was deduced as C-6 position.

\section{ii. Synthesis of thiolignin-(dialkyl phosphorothioate)}

By treating thiolignin with sodium hydride in $N$, N-dimethylformamide, thiolignin 0 -sodio derivative was obtained. The derivative was combined with dialkyl phosphorochloridothioate to afford thiolignin-(dialkyl phosphorothioate).

\section{iii. Pesticide combined with synthetic polymer}

Poly(vinyl chloride) (PVC) was heated with 3-amino-1, 2, 4-triazole (ATA), 2-imidazolidone (IM) or 2-imidazolidinethione (IMT) above the melting point of each nucleophile from 4 to 96 hours to give products containing the nucleophilic substituent. It was supposed that hydrogen atom of N-l imine of ATA and amidic hydrogen of IM or IMT were substituted for chlorine of PVC. Among these preparations the polymer combined with ATA exhibited a selective and strong herbicidal activity. Other biological activities of these compounds were described briefly.

\section{iv. Herbicidal synthetic polymer}

Copoly(S-vinyl isothiourea-vinylene-vinyl thiocyanate) was prepared from poly(vinyl chloride) with thiourea as an attempt for controlled-release herbicide. The copolymer was decomposed by aqueous alkaline solution to give polymer thiolate, thiocyanate and other compounds. The copolymer was also decomposed by acid releasing low molecular compounds. The copolymer was not effective for germination but inhibited the growth of seedlings of barnyard grass for 28 days in a soil sample. The copolymers treated with acid or base were no more effective on the germination and the growth of the plant.

v. Synthesis of poly(S-vinyl alkyldithiocarbamate)s

Poly $(S$-vinyl alkyldithiocarbamate)s were prepared from poly(vinyl chloride) and sodium alkyldithiocarbamates in dimethylformamide. These derivatives 
were decomposed by exposure to light or by acid or base treatment to give sulfur, sulfur-containing compounds and others. The polymer showed herbicidal and fungicidal activities.

\section{Natural products}

\section{i. Isolation and identification of phenolic acids in rice vinegar}

The fractions obtained from the ether soluble part of rice vinegar were separated by means of cellulose column and of Amberlite XE-64 ion exchange resin. The following compounds were identified : p-hydroxyphenylethanol, $p$ hydroxyphenylacetic acid, p-hydroxyphenyllactic acid, p-hydroxybenzoic acid and phenyllactic acid.

\section{ii. Aromatic components of rice vinegar}

This paper deals with the gas chromatographic investigation of volatile fractions and a column chromatography of a neutral phenolic fraction. As the result of gas chromatographic studies, 15 components were confirmed in neutral low boiling fraction and 5 components in acidic low boiling fraction. The neutral phenolic fraction was separated by means of a cellulose column and 3 components were recognized.

\section{iii. Essential oils of some orange peels}

The essential oils contained in the peels of Kabusu, Sudachi, Iyokan, Daidai and Natsudaidai oranges were studied by gas chromatography. The major components of each essential oil were d-limonene, $\beta$-pinene, camphene, 1 , 8-cineol, and caprylaldhyde. As minor components there found 23 compounds in Kabusu, 14 in Sudachi, 9 in Iyokan, 14 in Natsudaidai, and 11 in Daidai oil.

iv. Jelly substance extruded from eggs of Nereis japonica Izuka

From eggs of Nereis japonica Izuka a jelly substance was obtained as electrophoretically and ultracentrifugally homogeneous component by means of fractional precipitations. This substance was composed of $35 \%$ of carbohydrate, $30 \%$ of protein, and other minor constituents. A single peptide which consisted of 17 moles of amino acids was combined at somewhere of carbohydrate chain which was built by a manner of $\beta$-type from a repeating unit of 8 moles of glucuronic acid and 5 moles of neutral sugar.

\section{v. Antifungal substances produced by Cephalothecium roseum Corda}

No antifungal activity could be recognized in the acidic or basic fractions obtained from the culture filtrate of Cephalothecium roseum Corda, which was not in accordance with Yoshii's description (Yoshii, 1957). The active substances were found only in ether soluble neutral fraction. A major antifungal substance of them, $\mathrm{C}_{19} \mathrm{H}_{24} \mathrm{O}_{5}$ was identified as trichothecin (Freeman, 1955).

\section{vi. Brefeldin A from a strain of Fungi Imperfecti}

Nishimura and Kubo isolated a strain of Fungi Imperfecti which produces an antifungal metabolite. The metabolite was obtained in a crystalline state from the mycelia extract. The elementary analysis and spectral data implied that the compound is a dihydric alcohol containing a carbonyl group. A crude metabolite was purified by acetylation and a preparative TLC to give colorless needles, m. p. $129-130^{\circ} \mathrm{C}$, of the molecular formula $\mathrm{C}_{20} \mathrm{H}_{28} \mathrm{O}_{6}$. In the NMR spectrum of the acetate 2 acetoxyl groups and a secondary methyl group were 
inferred from the signals singlet at $\tau 7.91,8.0$, and 8.77 respectively. Based on the molecular formula and spectral data, it was deduced that the antifungal metabolite is a dihydruxy bicyclic dienc ester (or lictone) or a dihydroxy monocyclic tricneester (or lactonc). Tht physical properties including IR and NMR data of the acetate agreed in every respect with those of brefeldin A diacetate (Sigg, 1964).

\section{Miscellaneous}

i. Utilization of bulbs of Lycoris radiata Herb.

Experiments on the saccharification of the bulbs of Lycoris radiata and alcoholic fermentation of saccharified solution werecarried out under various conditions. Thesaccharification went forward to $72 \%$ and $70 \%$ by Koji and Taka-diastase respectively, and a bitter solution was obtained. However, the alcoholic fermentatin was very difficult. After treated with carbon, kaolin, and japanese acid clay, the solution was fermentable at the rates of $83 \%, 54 \%$ and $58 \%$ respectively. This is presumably due to the fact that the noxious substance has been absorbed by these materials. When $2 \%$ of carbon was employed and $0.2-O .5 \%$ of $\left(\mathrm{NH}_{4}\right)_{2} \mathrm{SO}_{4}$ was added, the results showed the highest degree.

From the carbon used for the absorption, there were obtained lycolin and other not defined substance which seems especially harmful to yeast.

ii. Photochemical degradation of polychlorinated hydrocarbons

Polychlorinated hydrocarbons are stable and resist towards oxidation, hydrolysis and other chemical reactions which conceivably occur in the environment. In alcoholic potassium hydroxide solutions, polychlorinated biphenyls mixture (PCB; Kanechlor 400), the insecticides BIIC and DDT, and the fungicide pentachlorobenzyl alcohol were irradiated with a mercury high pressure lamp (100w) at $35^{\circ} \mathrm{C}$ for 13 hours.

When isopropanol was used as a solvent, Kanechlor $400(\mathrm{KC}-400)$ was dechlorinated entirely, and isopropanol was converted into acetone. Thus, the principal reaction seemed to be a progressive reductive dechlorination. However when ethyl alcohol was used as a solvent, various polar compounds were produced owing probably to photo-nucleophilic substitution followed by photooxidation.

Lindane or DDT was mixed with isopropanol, which contained potassium hydroxide and similarly irradiated. The equivalents of 75.2 is of chlorine contained in lindane and $42.5 \%$ of chlorine in DDT were liberated in the form of ion. Pentachlorobenzyl alcohol (PCBA) was added to methanolic KOH solution and irradiated. It was shown that $57 \%$ of the chlorine contained in PCBA, which is 3 atom equivalents of 5 chlorine atoms in the molecule, was liberated. When a similar experiment by using isopropanol as a solvent in place of methanol, $79 \%$ of the chlorine, which is 4 atom equivalents, was converted to the ionic form.

iii. Thermal decomposition of bis-(O,O-dimethylthionophosphoryl) disulfide

The thermal decomposition of bis-(O,O-dimethylthionophosphoryl) disulfide under the anhydrous condition was studied. The redox potential of system of the disulfide and 0,0-dimethyldithiophosphoric acid was measured by the polaro- 
graphical met hod as $-9.304 \pm 0.005 \mathrm{~V}$ vs. normal hydrogen electrode. It was revealed by a differential thermal analysis that an exothermal reaction started at about $140^{\circ} \mathrm{C}$ and reached the maximum at $174^{\circ} \mathrm{C}$. At this point the weight loss was about $39 \%$. Thus, the disulfide decomposed explosively at about $140^{\circ} \mathrm{C}$ and evolved a gaseous mixture.

Gas produced by the pyrolysis of the disulfide was separated by gas chromatography and analyzed by mass spectrometry. As a result, $\mathrm{CH}_{3} \mathrm{SH}$, $\mathrm{CH}_{3} \mathrm{SCH}_{3}, \mathrm{CH}_{3} \mathrm{SSCH}_{3},\left(\mathrm{CH}_{3} \mathrm{O}\right)_{2} \mathrm{P}(\mathrm{O}) \mathrm{SCH}_{3},\left(\mathrm{CH}_{3} \mathrm{O}\right)_{2} \mathrm{P}(\mathrm{S}) \mathrm{CH}_{3}$ and others were identified from the decomposition products.

iv. Insecticidal effectiveness of thiourea derivatives

As to about forty thiourea derivatives and some thiol compounds, effects on pupation and imago emergence of housefly larvae were examined by feeding and dipping tests. As the result, it was elucidated that $N$-benzoyl- $N^{\prime}$-( $p$-dimethylamino)-phenylthiourea, 3-( $p$-chlorophenyl)-thioureide-propionic acid and $\mathrm{N}$-(3,4methylenedioxy)-benzolyl- $N^{\prime} \cdot\left(3^{\prime}, 6^{\prime}\right.$-dichloro- $2^{\prime}$-methoxy)-phenylthiourea inhibited markedly the imago emergence, but inhibited the pupation little. Moreover, some of the effective compounds restrained the anterior inhibition, suggesting that the inhibitory activity was concerned with depriving of metals.
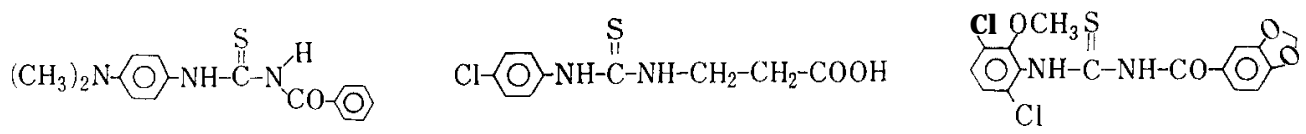

v. Studies on fluorine in the waste matter in shelling oystes

Shelling oyster shell, mussel, sea squirt and other livings are all thrown away as waste matter. As to this waste matter, fluorine content was estimated. The total fluorine content in crushed and shieved oyster shell varied according to the size of the oyster shell particles, being higher in fine particles than in coarse ones. About $30 \%$ of the total fluorine in the waste matter was soluble in water and about $65 \%$ was soluble in acid, and the latter was assumed to be $\mathrm{CaF}_{2}$. Some ether-soluble fluorine assumed to be organic fluorine compounds contained in mussel and sea squirt but not in the waste matter.

$\mathrm{vi}$. Chemical properties of quinol phosphate esters and inhibition of alcohol dehydrogenase by them

Some phosphate and phosphorothiolatesters of hydroquinone and related phenols and thiophonols were prepared. Quinol phosphates were stable to alkaline hydrolysis but susceptible to oxidation. They inhibited yeast alcohol dehydrogenase probably owing to the oxidatively produced quinone.

\section{DISCUSSION}

The present paper deals with'to prepare biologically active compounds and to elucidate the relationship between constitutions and biological activities. Namely, about 500 compounds were prepared anew. There are benzimidazole-, triazine-derivatives which involved the carboxyl group of amino acids and peptides into their rings, triazolo-, as well as thiadiazolopyrimidine, guanidino- 
pyrimidine, isocoumarin, morpholinone, dithianethione, etc.

Biological activities, particularly toward plants, fungi, and insects, as well as tumor cells, of these compounds were scrutinized. As the results, some biologically active compounds were found. Especially, there were interesting compounds among thiadiazolopyrimidines, guanidinopyrimidines, isocoumarin derivatives. Thus, alkanesulfinyl (or sulfonyl) derivatives of thiadiazolopyrimidine showed strong anti-tumor activity against Ehrlich ascites tumor cells.

However, as to the relationship between constitution and activity, no allpowerful conclusion was deduced.

Starting from periodate oxidation of carbohydrates, new polysaccharides such as nitro-dextran and amino-dextran were prepared, while triazinized polysaccharides were derived from pectin and alginic acid. Furthermore the oxidized starch was combined with various amino acids. However, at these reactions the yield of products was unsatisfactory.

On the other hand, as to protein chemistry, by various chemical modifications devised by the author such as periodate oxidation, glucosylamidination, reaction with ethylene oxide etc. the relationship between the constitutions and the biological activities was pursued. In this case, the extent of reactions was inevitably not sufficient in order to avoid denaturation.

The constitution of an allergenic substance isolated from liver flukes was elucidated. However, it is requisite to confirm by the synthesis. Especially, important problems such as the meaning of peptide moiety existing in the allergen, removing of that peptide from the RNA, and reconstructing etc. are still remaining.

Since an RNA fraction isolated from Ehrlich ascites tumor cells combines with peptide moiety, it is necessary to clarify a common role of peptide. The tumor-repressing activity by means of RNA-complex formation seems to be a host-mediated phenomenon. Eventually it is inferred as an immunopotentiation. However, as to further mechanism it is remained to study.

The chemistry of natural products, which is concerned with to find substances involved in certain biological phenomena and to elucidate their chemical structures, has been always the most attractive domain, since discovery of vitamins and hormones. However, once in a great while the compounds obtained after all efforts are well known compounds.

On the other hand, to find certain biological significances as to synthesized compounds it may be also important. Nevertheless, for this way, tedious survey on bioassay is necessay naturally.

On the whole, the contribution by both of ways may be as dependent as the wheels of a cart.

\section{REFERENCES}

Appel, A., R. Kleinstück und K.-D. Ziehn 1971 Über die gemeinsame Einwirkung von Phosphinen und Tetrachlorkohlenstoff auf Ammoniak (Derivate), II. Eine einfache NitrilSynthese. Chem. Ber., 104: 1030-1035

Baeyer, A. 1877 Ueber das Furfurol. Ber., 10: 695-698 
Desnuelle, P., S. Antonin et A. Casal, 1947 Precipitation de l'albumen d'œuf par sodium periodate. Bull. Soc. Chim. Biol., 29: 694-701

Eilingsfeld, H. und H. Scheuermann 1967 Synthese von 1,3,5-Triazinen. Chem. Ber., 100 : 1874-1891

Fraenkel-Conrat, H. 1914 The action of 1,2-epoxides on proteins. J.Biol. Chem., 154: $227-238$

Fraenkel-Conrat, H. 1950 The essential groups of lysozyme, with particular reference to its reaction with iodine. Arch. Biochem., 27: 109-124

Freeman, G. G. 1955 Further biological properties of trichothecin, an antifungal substance from Trichothecium roseum Link, and its derivatives. J. Gen. Microbiol,, 12: 213-221

Fukumoto, J. 1943 Studies on bacterial amylase. III. Conditions of amylase production (1). J. Agr. Chem. Soc. Jay., 19: 689-692

Hamamura, Y. and K. Naito 1956 Studies on the micro constituent in mulberry leaves, Part I. Bull. Agr. Chem. Soc. Jap., 30: 358-361

Higuchi, M., I. Sakata and R. Senju 1970 Kinetic study on Hofmann reaction of carbamoylethyl starch. Kogyo Kagaku Zasshi, 73: 421-430

Jayme, G. und M. Sätre 1942 U̇ber die Oxydation des Xylans mit Perjodsaure. Ber., 75 : $1840-1850$

Kano, H. and Y. Makisumi 1958 Synthesis of potential anticancer agents, I. 5-Substituted 7-methyl-s-triazolo [4,3-a] - and -tetrazolo [1, 5-a] -pyrimidines. Chem. Pharm. Bull., 6: $583-586$

Mandell, J. D. and A. D. Hershey 1960 A fractionating column for analysis of nucleic acids. Anal. Biochem., 1: 66-77

Martin, A. J. P. and R. L. M. Synge 19.11 Some applications of periodic acid to the study of the hydroxyamino-acids of protein hydrolysates. Biochem. J., 35: 294-314

Micheel, F. und W. Berlenbach 1952 Eine neue Methode zur Darstellung von KohlenhydratAminoslure-Derivaten und verwandten Verbindungen. Chem. Ber., 85 : 189-192

Micheel, F. und B. Herold 1953 Synthetische Glucose-Derivate von Proteinen. Z. physiol. Chem., 293: 187-190

Phillips, M. A. 1929 The formation of 1-substituted benzimidazoles. J. Chem. Soc, 1929: 2820-2832

Rackmann, K. 1910 Untersuchungen über Diguanide und einige daraus hergestellte Verbindungen. Liebigs Ann. Chem., 376: 163-183

Schrader, G. and W. Zerweck 1934 Arylenethiazoles. Germ. Pat., 603,623, Oct. 8; Chem. Abst., 29: 814 (1935)

Schroeder, W. A. 1952 Sequence of four amino acids at the amino end of the single polypeptide chain of lysozyme. J. Amer. Chem. Soc., 74; 5118-5124

Senju, R. 1962 The utilization of high polymer amines in paper and pulp factories. In "Drugs and Technics in Paper and Pulp", Shigyo Journal Co., pp. 809-821

Sigg, H. P. 1964 Die Konstitution von Brefeldin A. Helv.Chim. Acta, 47: 1401-1415

Smith, F. and H. C. Srivastava 1959 Constitutional studies on the glucomannan of Konjak flour. J. Amer. Chem. Soc., 81: 1715-1718

Straumfjord, J. V. and J. P. Hummel 1959 Microelectrophoresis of ascites tumor cells and the effect of polyxenyl phosphate. Cancer Res., 19: 913-917

Terminiello, L., M. Bier and F. F. Nord 1958 On the mechanism of enzyme action. LXIV. Succinyltrypsin and the reversibility of its denaturation. Arch. Biochem. Biophys., 73: 171-179

Wada, K. and N. Yoshinaga 1969 Structure of imogolite. Amer. Mineral., 54: 50-71

Yoshii, H. 1957 Studies on the disease resistance in rice plants. Mem. Ehime Univ., Sect. VI. 3: 1-149 